\title{
Kisspeptin Neuron-Specific and Self-Sustained Calcium Oscillation in the Hypothalamic Arcuate Nucleus of Neonatal Mice: Regulatory Factors of its Synchronization
}

\author{
Doyeon Kim a, b Sangwon Jang ${ }^{\mathrm{a}}$ Jeongah Kim ${ }^{\mathrm{a}}$ Inah Park ${ }^{\mathrm{a}}$ Kyojin Ku ${ }^{\mathrm{a}}$ \\ Mijung Choi ${ }^{a}$ Sukwon Lee ${ }^{c}$ Won Do Heo ${ }^{d}$ Gi Hoon Son ${ }^{e}$ Han Kyoung Choe ${ }^{a}$ \\ Kyungjin Kim ${ }^{\text {a }}$ \\ ${ }^{a}$ Department of Brain and Cognitive Sciences, Daegu Gyeongbuk Institute of Science and Technology (DGIST), \\ Daegu, South Korea; ${ }^{b}$ Interdisciplinary Program in Neuroscience, College of Natural Sciences, Seoul National \\ University, Seoul, South Korea; ' $D$ Department of Neural Development and Disease, Korea Brain Research Institute, \\ Daegu, South Korea; ${ }^{\mathrm{d}}$ Department of Biological Sciences, Korea Advanced Institute of Science and Technology

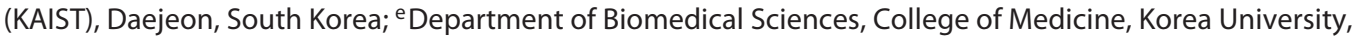 \\ Seoul, South Korea
}

\section{Keywords}

Arcuate nucleus $\cdot$ Kisspeptin $\cdot \mathrm{Ca}^{2+}$ oscillation .

Synchronization · Neonate

\begin{abstract}
Introduction: Synchronous and pulsatile neural activation of kisspeptin neurons in the arcuate nucleus (ARN) are important components of the gonadotropin-releasing hormone pulse generator, the final common pathway for central regulation of mammalian reproduction. However, whether ARN kisspeptin neurons can intrinsically generate self-sustained synchronous oscillations from the early neonatal period and how they are regulated remain unclear. Objective: This study aimed to examine the endogenous rhythmicity of ARN kisspeptin neurons and its neural regulation using a neonatal organotypic slice culture model. Methods: We monitored calcium $\left(\mathrm{Ca}^{2+}\right)$ dynamics in real-time from individual ARN kisspeptin neurons in neonatal organotypic explant cultures of Kiss1-IRES-Cre mice transduced with genetically encoded $\mathrm{Ca}^{2+}$ indicators. Pharmacological approaches were em-
\end{abstract}

karger@karger.com www.karger.com/nen

Karger $\frac{1}{\%}$

GOPEN ACCESS
(C) 2020 The Author(s)

Published by S. Karger AG, Basel

This article is licensed under the Creative Commons AttributionNonCommercial-NoDerivatives 4.0 International License (CC BYNC-ND) (http://www.karger.com/Services/OpenAccessLicense) Usage and distribution for commercial purposes as well as any distribution of modified material requires written permission. ployed to determine the regulations of kisspeptin neuronspecific $\mathrm{Ca}^{2+}$ oscillations. A chemogenetic approach was utilized to assess the contribution of ARN kisspeptin neurons to the population dynamics. Results: ARN kisspeptin neurons in neonatal organotypic cultures exhibited a robust synchronized $\mathrm{Ca}^{2+}$ oscillation with a period of approximately $3 \mathrm{~min}$. Kisspeptin neuron-specific $\mathrm{Ca}^{2+}$ oscillations were dependent on voltage-gated sodium channels and regulated by endoplasmic reticulum-dependent $\mathrm{Ca}^{2+}$ homeostasis. Chemogenetic inhibition of kisspeptin neurons abolished synchronous $\mathrm{Ca}^{2+}$ oscillations, but the autocrine actions of the neuropeptides were marginally effective. Finally, neonatal ARN kisspeptin neurons were regulated by $\mathrm{N}$-methyl-D-aspartate and gamma-aminobutyric acid receptor-mediated neurotransmission. Conclusion: These data demonstrate that ARN kisspeptin neurons in organotypic cultures can generate synchronized and self-sustained $\mathrm{Ca}^{2+}$ oscillations. These oscillations controlled by multiple regulators within the ARN are a novel ultradian rhythm generator that is active during the early neonatal period.

(c) 2020 The Author(s)

Published by S. Karger AG, Basel 


\section{Introduction}

Kisspeptin, encoded by the Kiss 1 gene, is a neuropeptide that plays a crucial role in development and regulation of reproduction. By binding to its receptor, Kiss $1 \mathrm{R}$ (or GPR54), kisspeptin can stimulate gonadotropin-releasing hormone $(\mathrm{GnRH})$ neurons that regulate secretion of gonadotropins from the anterior pituitary [1]. The hypothalamic GnRH content increases from the neonatal period $[2,3]$. Kisspeptin release observed in the adult period is pulsatile, with $75 \%$ of kisspeptin pulses correlating with GnRH pulses [4]. However, whether kisspeptin neurons are active from the early stage of development, and whether neonatal arcuate nucleus (ARN) kisspeptin neurons can generate pulsatility on their own, is yet to be determined.

Kisspeptin neurons in the ARN, located on both sides of the third ventricle, develop at embryonic day 16.5 and become synaptically connected to GnRH neurons [5], unlike another kisspeptin population in the anteroventral periventricular nucleus (AVPV) detected at later developmental stages [6]. Kisspeptin neurons are thought to "time" reproduction by coordinating inputs for maturation and regulation of the GnRH pulse generator [7]. Loss-of-function mutations in Kiss1R cause the absence of sexual maturation [8]. In addition, ARN kisspeptin neurons coexpressing neurokinin $\mathrm{B}(\mathrm{NKB})$ and dynorphin (Dyn), known as KNDy neurons, can auto-regulate ARN kisspeptin neurons $[9,10]$, suggesting that ARN kisspeptin neurons are a potential pulse generator. Indeed, luteinizing hormone (LH) secretion, a surrogate marker of GnRH secretion, was tightly correlated with the $\mathrm{Ca}^{2+}$ dynamics of ARN kisspeptin neurons [11]. However, whether ARN kisspeptin neurons themselves can generate the rhythm has yet to be determined. Considering the finding that ARN kisspeptin neurons have been shown to coordinate circadian input from the suprachiasmatic nucleus and control feeding, locomotor activity, body temperature, and sleep pattern [12], it is essential to address whether ARN kisspeptin neurons are able to generate rhythm on their own and identify the inputs that are involved in their regulation.

The hypothalamic GnRH pulse generator that governs pituitary secretion of gonadotropins is a well-characterized ultradian rhythm important for central regulation of mammalian reproduction $[13,14]$. The importance of the pulse was revealed when intermittent administration of GnRH led to pulsatile gonadotropin secretion, while constant infusion had desensitized the pituitary response in monkeys [15]. Subsequently, pulsatile GnRH secretion was validated in other animals including rodents, sheep, and even humans [3]. GnRH neurons exhibit pulsatile secretion and synchronized burst activities even in immortalized cells, yet the origin of the pulse generator still remains elusive [16].

Our recent study demonstrated that pulsatile kisspeptin administration to the preoptic area evokes synchronous $\mathrm{GnRH}$ promoter activity, indicating that kisspeptin inputs to $\mathrm{GnRH}$ neurons are important in $\mathrm{GnRH}$ pulse generation [17]. Also, a series of elegant studies on the driver of pulsatile $\mathrm{GnRH}$ activity was performed. For instance, optogenetic activation of GnRH neurons [18] or the hypothalamic ARN kisspeptin neurons [19] generated pulsatile LH secretion in both cases. In adult mice, ARN kisspeptin neurons exhibited synchronized $\mathrm{Ca}^{2+}$ oscillations in vivo that correlated with pulsatile $\mathrm{LH}$ secretion [11]. Kisspeptin neurons in the ARN are, thus, considered an important regulator of the GnRH pulse generator $[13,14]$.

Monitoring changes in intracellular $\mathrm{Ca}^{2+}$ concentration using genetically encoded $\mathrm{Ca}^{2+}$ indicators offers access to cell type-specific $\mathrm{Ca}^{2+}$ dynamics to characterize neuronal physiology [20]. GnRH neurons in cell culture or acute brain slices display spontaneous $\mathrm{Ca}^{2+}$ transients that correlate with their burst firing pattern [21, 22]. Although ex vivo incubation procedures may introduce alterations in neuronal characteristics, the organotypic slice culture model with genetically encoded $\mathrm{Ca}^{2+}$ indicators is a useful model for understanding neural oscillation ranging from circadian to ultradian rhythm. Recently, ultradian rhythms of $\mathrm{Ca}^{2+}$ oscillations were observed in hypothalamic slices in the subparaventricular zone and paraventricular nucleus that was transmitted to the suprachiasmatic nucleus [23]. Organotypic cultures, as demonstrated in the study with subparaventricular zone and paraventricular nucleus, can preserve functional features of the original tissue, allowing for in vitro molecular and cellular investigation [24]. In this study, using a single cell imaging system, we examined the ultradian $\mathrm{Ca}^{2+}$ oscillation in neonatal ARN kisspeptin neurons ex vivo and the regulatory components that contribute to the generation of $\mathrm{Ca}^{2+}$ oscillations.

\section{Materials and Methods}

Animals

Kiss 1-IRES-Cre knock-in mice were generously provided by Dr. Ulrich Boehm (Saarland University, Germany) [25]. Gt(ROSA)26Sor<tm14(CAG-tdTomato)Hze>/J (Ai14) mice [26] were used to label kisspeptin neurons with Cre-dependent tdTo- 
mato reporter (online suppl. Fig. S1A; for all online suppl. material, see www.karger.com/doi/10.1159/000505922). Slc6a3<tm1.1(cre) $\mathrm{Bkmn}>/ \mathrm{J}$ (dopamine transporter-IRES-Cre, DAT-IRES-Cre) mice [27] were used to examine another neural population in the ARN. Pups were housed under a 12:12 h light-dark cycle (lights on at 7: 00 a.m.) and constant temperature $\left(22-23^{\circ} \mathrm{C}\right)$ with their mothers before being sacrificed. Food and water were provided ad libitum. In order to identify kisspeptin neurons, Kiss1-IRES-Cre mice were crossed with Ail4 to label kisspeptin neurons with tdTomato [26]. Neonatal mice were genotyped by PCR using genomic DNA from toe clips prepared using the KAPA mouse genotyping kit (Roche, Basel, Switzerland), and heterozygous mice were used. Animal experiments were conducted in compliance with the rules and regulations established by the Institutional Animal Care and Use Committee of Daegu Gyeongbuk Institute of Science and Technology.

\section{Organotypic Slice Culture}

Organotypic slice culture was prepared as described previously [17] with some modifications. Briefly, the brains of the neonatal mice (postnatal day 6-8) were obtained and rapidly placed in icecold Gey's balanced salt solution supplemented with $10 \mathrm{mM}$ HEPES and $30 \mathrm{~mm}$ glucose, bubbled with $5 \% \mathrm{CO}_{2}$ and $95 \% \mathrm{O}_{2}$. Coronal or horizontal slices ( $400 \mu \mathrm{m}$ thickness) were prepared using a vibratome (Leica, Nussloch, Germany). The ARN region located at $4.95-5.31 \mathrm{~mm}$ [28] was collected and dissected approximately $1 \mathrm{~mm}$ long and $1 \mathrm{~mm}$ wide along the third ventricle. Slices were explanted onto a culture membrane (Millicell-CM; Merck Millipore, Darmstadt, Germany) in culture media (50\% minimum essential medium, 25\% Gey's balanced salt solution, 25\% horse serum, $36 \mathrm{~mm}$ glucose, and $100 \mathrm{U} / \mathrm{mL}$ antibiotic-antimycotic). The medium was replaced every 3 days until experiments.

\section{Adeno-Associated Virus Transduction of ARN Slices}

Organotypic slices were stabilized for approximately 10 days before transduction with adeno-associated virus (AAV) addition [29]. AAV 2/1 $_{1}$-hSyn-Flex-GCaMP6m (\#100838, Addgene, Cambridge, MA, USA) or $\mathrm{AAV}_{2 / 1}$-hSyn-Flex-jRGECO1a (red-fluorescent genetically encoded $\mathrm{Ca}^{2+}$ indicator for optical imaging, Addgene 100853) was dropped directly onto the surface of the ARN slice $(1 \mu \mathrm{L}$ per slice). After transduction, the slices were incubated for another 10 days for the virus to express. For pan-neuronal $\mathrm{Ca}^{2+}$ imaging, $\mathrm{AAV}_{2 / 1}$-hSyn-GCaMP6m (Addgene 100841) was used to transduce nonspecific neuronal population of the ARN. For chemogenetic studies, AAV encoding either hM $4 D\left(G_{i}\right)$ mCherry (Addgene 44362) or $\mathrm{hM} 3 \mathrm{~d}\left(\mathrm{G}_{\mathrm{q}}\right)$-mCherry (Addgene 44361) under the control of human synapsin promoter in a Cre DNA recombinase-dependent manner for inhibition or activation was added after the application with Syn-Flex-GCaMP6m. The Designer Receptors Exclusively Activated by Designer Drugs (DREADD) systems were activated by clozapine-N-oxide (CNO) application [30]. The viral titer was $2.69-3.842 \mathrm{e}^{13} \mathrm{GC} / \mathrm{mL}$ and was diluted in phosphate-buffered saline (PBS) to $5.38 \mathrm{e}^{12}-1.92 \mathrm{e}^{13}$ $\mathrm{GC} / \mathrm{mL}$ before use.

\section{Real-Time Fluorescence and Bioluminescence Imaging}

Intracellular $\mathrm{Ca}^{2+}$ levels in ARN slices were monitored using a custom device, Circadian 700B (Live Cell Instrument, Seoul, South Korea). The imaging system was composed of an electron multiplying charge-coupled device (EM-CCD) camera $(512 \times 512$ pixels, iXon3; Andor Technology, Belfast, UK), Nikon S Fluor $4 \times$ or
$20 \times$ objective lenses, and LED-Excitation System (Live Cell Instrument) with 480 and $525 \mathrm{~nm}$ light sources used for excitation of GCaMP and RGECO, respectively. The slices were maintained in an incubating unit with the temperature controller set to $37^{\circ} \mathrm{C}$ and gas mixer set to $5 \% \mathrm{CO}_{2}$ (Live Cell Instrument). Fluorescence imaging was performed with an exposure time between 80 and 200 $\mathrm{ms}$. Imaging without an interval and $2-3 \mathrm{~s}$ intervals provided comparable results, so the experiments were performed with 2-3 s intervals using the NIS Software (Nikon, Tokyo, Japan). The fluorescence intensity of individual neurons was measured from regions of interest established for single neurons with the NIS software. Background fluorescence from each image was also measured and subtracted. Relative fluorescence changes were calculated as $\Delta \mathrm{F} / \mathrm{F}=\left(\mathrm{F}-\mathrm{F}_{0}\right) / \mathrm{F}_{0} \times 100$, where $\mathrm{F}_{0}$ was the baseline fluorescence intensity obtained by the mean fluorescence intensity from $30 \mathrm{~s}$ between the peaks (average of 3 values).

\section{Drug Treatments}

Drugs were diluted in the recording media (DMEM: Ham's F12 medium supplemented with $\mathrm{N} 2$ supplement, $36 \mathrm{mM}$ glucose, and $100 \mathrm{U} / \mathrm{mL}$ antibiotic-antimycotic) to the indicated concentrations and perifused at a flow rate of $2.4 \mathrm{~mL} / \mathrm{h}$. For luminescence imaging, $1.5 \mathrm{~mm}$ luciferin was added to the recording media. After the baseline oscillation was obtained, drug-containing media were applied for 15-30 min and were washed out with recording media for the same time period. Tetrodotoxin (TTX, voltage-gated sodium channel blocker), 4-aminopyridine (4-AP, voltage-gated potassium channel blocker), mibefradil (T-type $\mathrm{Ca}^{2+}$ channel blocker), mefloquine (blocker of gap junctions composed of connexin [Cx] $36,50)$, senktide (Senk, neurokinin 3 receptor [NK3R] agonist), SB222200 (NK3R antagonist), nor-binaltorphimine dihydrochloride (nor-BNI, kappa-opioid receptor [KOR] antagonist), D-(-)2-amino-5-phosphonopentanoic acid (D-AP5, N-methyl-D-aspartate [NMDA] receptor antagonist), and bicuculline (gammaaminobutyric acid [GABA] type A receptor antagonist) were purchased from Tocris (Bristol, UK). Verapamil (voltage-gated $\mathrm{Ca}^{2+}$ channel blocker), tetanus toxin (TeNT, neurotransmitters release inhibitor), heparin (inositol 1,4,5-triphosphate $\left[\mathrm{IP}_{3}\right]$ receptor blocker), thapsigargin (sarco/endoplasmic reticulum (ER) $\mathrm{Ca}^{2+}$ ATPase [SERCA] inhibitor), and oleic acid (blocker of gap junctions composed of Cx 43) were purchased from Sigma-Aldrich (St. Louis, MO, USA). CNO was purchased from Enzo Life Sciences (Farmingdale, NY, USA), Dyn was purchased from Phoenix Pharmaceuticals (Burlingame, CA, USA). Kisspeptin-10 [31] was synthesized from Anygen (Gwangju, Korea).

\section{Immunohistochemistry}

Kisspeptin antiserum AC566 was generously provided by Dr. M. Beltramo and Dr. A. Caraty (INRA, France) [32]. For immunostaining, mice were perfused with $4 \%$ paraformaldehyde (PFA) in PBS, and brains were postfixed for $12 \mathrm{~h}$ in $4 \%$ PFA before sectioning ( $40 \mu \mathrm{m}$ thickness). Brain sections were collected in 12 wells, and sections in every 3 wells were used. Brain sections containing ARN [28] were blocked with $10 \%$ goat serum, $0.3 \%$ Triton X-100 in PBS, and then kisspeptin antiserum (1:2,500 in blocking solution) was applied overnight at $4{ }^{\circ} \mathrm{C}$. For organotypic slice immunostaining, slices on culture membrane were fixed with $4 \%$ PFA, blocked with $10 \%$ goat serum, $0.5 \%$ Triton $\mathrm{X}-100$ in PBS, and incubated overnight with kisspeptin antiserum at $4{ }^{\circ} \mathrm{C}$. 
Fluorescent in situ Hybridization

Cultured brain slices were fixed with 4\% PFA and sectioned into $12 \mu \mathrm{m}$ slices. The sections were mounted on SuperFrost Plus slides (Fisher Scientific 12-550-15), air-dried at $-20^{\circ} \mathrm{C}$, and stored at $-80^{\circ} \mathrm{C}$ until use. Using RNAscope (Advanced Cell Diagnostics [ACD], Hayward, CA, USA) protocol, the sections were boiled with Target Retrieval solution for $5 \mathrm{~min}$. Then, the sections were dehydrated in ethanol, and incubated with Protease for $30 \mathrm{~min}$ at $40^{\circ} \mathrm{C}$ using $\mathrm{HybEZ}$ oven. After probes were incubated, amplification was performed using the Fluorescent Multiplex Assay (ACD, 320850) following the manufacturer's instructions and protocols. Probes from ACD were used to detect mRNA levels: Mm-Kiss1 (500141), Mm-Kiss1R (408001), Mm-Tac2-C2 (446391-C2, encoding NKB), Mm-Tacr3-C3 (481671-C3, encoding NK3R), Mm-Pdyn-C3 (318771-C3, encoding Dyn), and Mm-Oprk1-C2 (316111-C2, encoding Dyn receptor, KOR). In certain occasions, fluorescent in situ hybridization (FISH) was followed by immunohistochemistry [33] to amplify GCaMP signals using $\alpha$-green fluorescent protein (GFP) antibody (Invitrogen A6455). After performing FISH and before $4^{\prime}, 6$-diamidine- $2^{\prime}$-phenylindole dihydrochloride (DAPI) staining, the sections were briefly washed with $0.1 \%$ TBST. Then the same blocking and antibody incubation steps were followed as in Immunohistochemistry. The number of Kiss 1 particles in the neurons was analyzed using ImageJ software (NIH, Bethesda, MD, USA) by defining regions of interest selected from GFP or DAPI signals (online suppl. Fig. S1C).

\section{Confocal Microscopy}

For observing the neuronal cell bodies at different depths within the slice, a confocal laser scanning microscope LSM 700 (Carl Zeiss, Oberkochen, Germany) was used. The images were obtained using Z-stack imaging, by scanning from the lowest to the highest position of the fluorescence signal. For identifying kisspeptin-positive neurons among tdTomato positive neurons and FISH analysis, LSM 800 (Carl Zeiss) was used. NeuroTrace (Invitrogen), a stain for Nissl bodies, or DAPI was used to identify positive signals within single neurons and avoid multiple counting. Cells were counted from 6 to 9 slices from each mouse.

\section{Statistical Analysis}

Peak interval and intensity of $\mathrm{Ca}^{2+}$ oscillations were calculated using the fast Fourier transform-nonlinear least squares function in BioDare (https://biodare2.ed.ac.uk) with adjusted time frame, and cells that were out of the linear min-max range were excluded. Peaks were identified using Cluster analysis [34]. In drug-treated experiments, the mean values of the peak interval in the 3 phases (pre-, treat-, and post-) were normalized relative to those of the same phases in the vehicle-treated control experiments and presented as " $\Delta$ peak interval," with the pre-phase set as 1 . Comparison between pre-, treat-, and post-phases was evaluated using repeated measures analysis of variance followed by post hoc Tukey test. In FISH experiments, comparison of Kiss 1 particles at the beginning and after culture was evaluated using unpaired two-tailed Student $t$ test. Statistical analyses were performed using Prism 5 (GraphPad Software, San Diego, CA, USA). The number of neurons analyzed for each experiment is indicated, and the number of mice includes gender information. Data are presented as the mean \pm SE. Significance was set at $p<$ 0.05 .

Kisspeptin Neuron-Specific $\mathrm{Ca}^{2+}$

Oscillation in ARN of Neonatal Mice

\section{Results}

\section{Kisspeptin Neuron-Specific Synchronized $\mathrm{Ca}^{2+}$}

\section{Oscillation in Mouse Hypothalamic ARN ex vivo}

To observe whether ARN kisspeptin neurons exhibit oscillations in the isolated state, we used organotypic ARN slice cultures from neonatal Kiss1-IRES-Cre mice. After stabilization for approximately 10 days ex vivo, kisspeptin neurons in the ARN were transduced with AAV expressing GCaMP6m in a Cre DNA recombinasedependent manner (Fig. 1a). In Kiss1-IRES-Cre; Ai14 mice (online suppl. Fig. S1A), $84.8 \pm 1.92 \%$ of tdTomatoexpressing neurons were quantified as kisspeptin-positive, suggesting that $\mathrm{Cre}$-mediated expression of tdTomato in ARN of Kiss1-IRES-Cre mice was indeed from kisspeptin-expressing neurons. To verify that Cre-expressing cells maintain the identity after 20 days of organotypic culture, FISH was performed at the beginning (4 days) and $>20$ days after culture. The number of Kiss 1 particles per cell after culture slightly decreased, but not significantly $(16.56 \pm 2.147$ for 4 days in culture and $13 \pm 1.744$ for $>20$ days in culture), compared to the beginning of culture (online suppl. Fig. S1B). To monitor single-cell intracellular $\mathrm{Ca}^{2+}$ dynamics, we acquired fluorescence signals with a custom real-time imaging system that infuses culture media and incubates the ex vivo slice (Fig. 1b). To confirm that the GCaMP signals come from kisspeptin neurons, Kiss 1 positive neurons were identified using FISH followed by immunohistochemistry using a-GFP to target GCaMP-positive neurons and detect both GCaMP immunoreactivity and Kiss 1 mRNA in the same cell (Fig. 1c). Approximately $80.1 \%$ of Kiss 1 positive neurons expressed GCaMP and $90.8 \%$ of GCaMP expressing neurons were Kiss1 positive (online suppl. Fig. S1C). Furthermore, immunostaining for kisspeptin peptide identified the expression of kisspeptin in Cre-dependent tdTomato-expressing neurons and Cre-dependent RGECO-expressing neurons (online suppl. Fig. S1A and D). To confirm the properties of the neurons after ex vivo culture, mRNA expression of Kiss1, Tac2, and Pdyn was examined using FISH (Fig. 1d). To a lesser extent, the neurons also expressed Kiss1R, Tacr3, and Oprk1 (Fig. 1d).

ARN kisspeptin neurons in the organotypic slice cultures transduced with AAV expressing Cre-dependent GCaMP displayed bright fluorescence. Real-time imaging of GCaMP activity revealed a robust fluctuation of the cytosolic $\mathrm{Ca}^{2+}$ concentration as shown in the consecutive line scan image of the indicated vertical line (Fig. 1e; also see online suppl. Fig. S2, and online suppl. movie 1). The fluorescence intensity of individual neurons exhibited a 

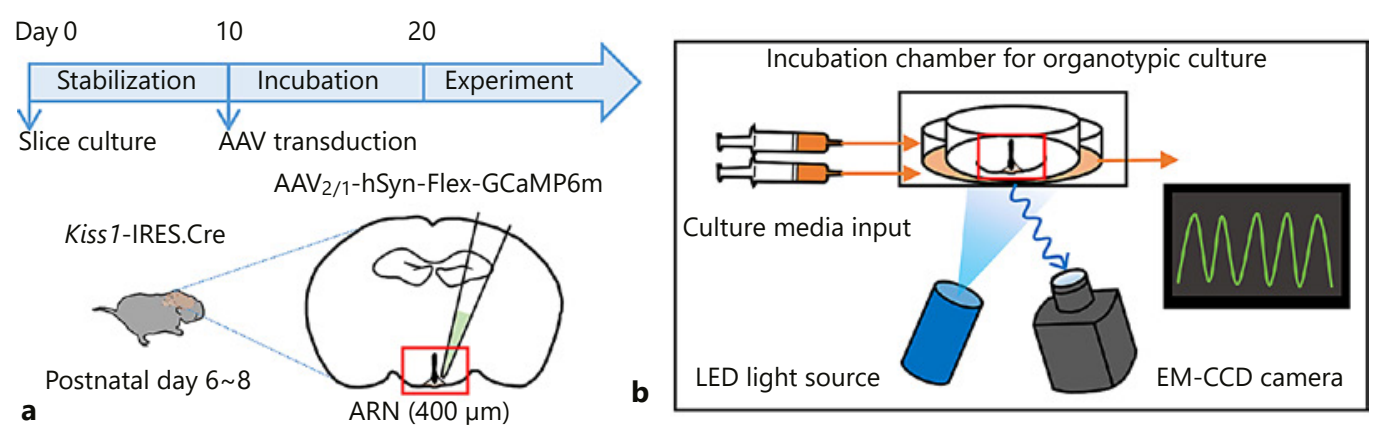

a
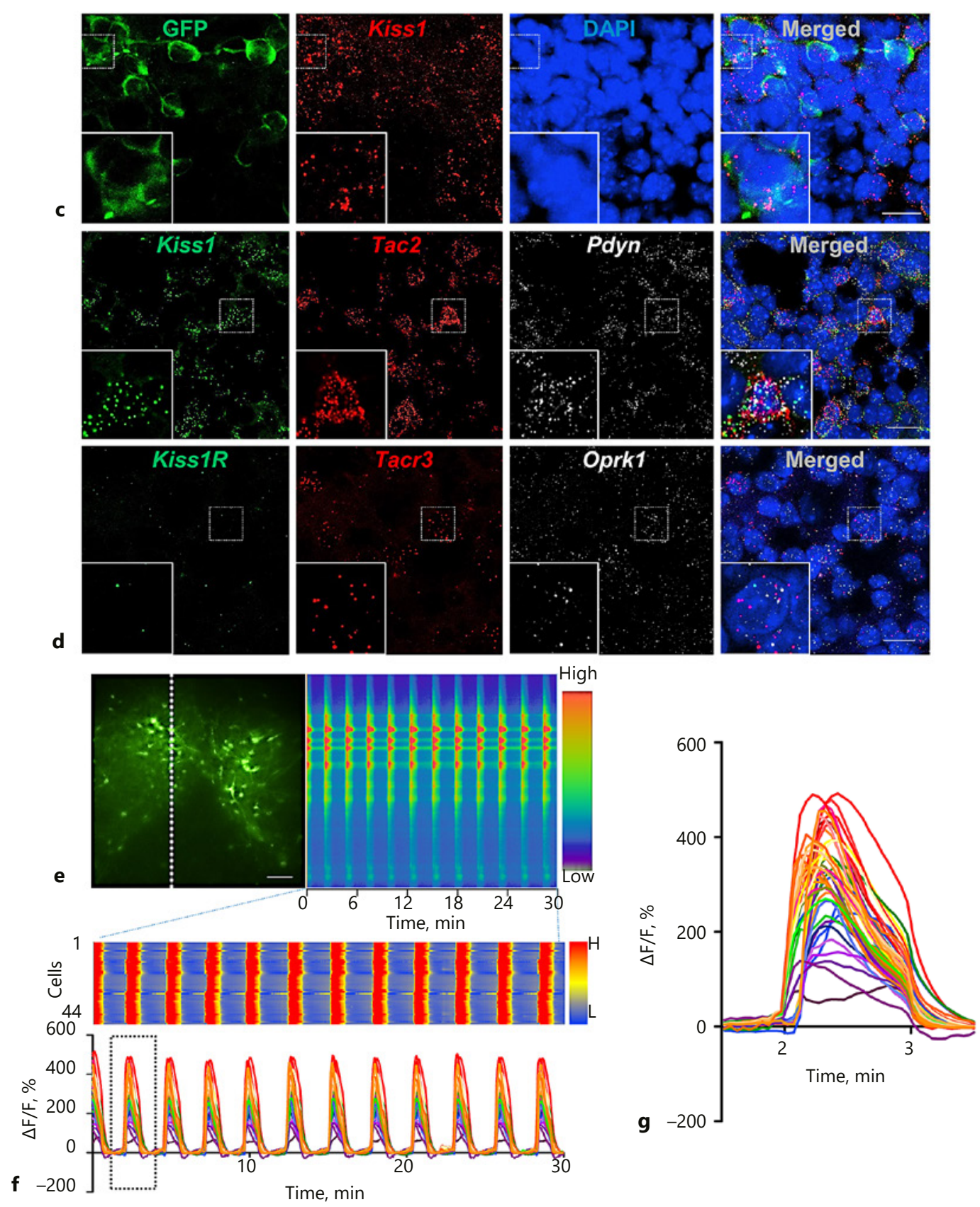

1

(For legend see next page.)

Kim/Jang/Kim/Park/Ku/Choi/Lee/Heo/ Son/Choe/Kim 
robust synchronization throughout the 30 -min recording (Fig. 1f; also see online suppl. Fig. S3 for individual $\mathrm{Ca}^{2+}$ profiles). A closer look at a single synchronized bout (dotted box in Fig. 1f) shows that the shape of GCaMP fluctuation is similar among synchronized ARN kisspeptin neurons with fluorescence intensity rising and falling collectively for a period of approximately $3 \mathrm{~min}$ with amplitude variations (Fig. 1g). There was no discernible effect of genetically encoded $\mathrm{Ca}^{2+}$ indicators in detecting the synchronized oscillations as the $\mathrm{Ca}^{2+}$ transients detected from 2 different indicators, GCaMP6m and jRGECO1a, expressed in the same neuron, exhibited similar oscillating patterns (online suppl. Fig. S4A). There was an amplitude difference between the $2 \mathrm{Ca}^{2+}$ indicators, but the period was not different. Therefore, either GCaMP or RGECO was used to monitor $\mathrm{Ca}^{2+}$ oscillations throughout the experiments. Also, single peaks obtained from different mice were analyzed (online suppl. Fig. S4B). Some peaks appeared spiky, while other peaks exhibited smooth paths. This variation did not originate from gender or reporter differences. Most of the peaks had a sharp rise and two-phase decay. The active and silent phase durations were, in most cases, 1 min active- 2 min silent or 2 min active-1 min silent. The percentage of cells showing intracellular $\mathrm{Ca}^{2+}$ concentration fluctuation from all GCaMP6m- or jRGECO1a-expressing cells was $97.06 \%$ (online suppl. Fig. S4C).

\section{Histological Validation of Synchronized $\mathrm{Ca}^{2+}$}

Oscillation in ARN Kisspeptin Neurons

Confocal imaging of the ex vivo slices expressing the $\mathrm{Ca}^{2+}$ indicator revealed differences in fluorescence inten-

Fig. 1. Kisspeptin neuron-specific synchronized $\mathrm{Ca}^{2+}$ oscillation in mouse hypothalamic ARN ex vivo. a Experimental scheme for ARN kisspeptin neuron-specific $\mathrm{Ca}^{2+}$ imaging in organotypic slices. Timeline for ARN slice preparation, stabilization, and AAV transduction to kisspeptin neurons. b Real-time biorhythm imaging scheme in a custom imaging system, Circadian 700B. c FISH using probe targeting Kiss 1 followed by immunohistochemistry using a-GFP to target GCaMP positive neurons. Scale bar $20 \mu \mathrm{m}$. d FISH using probes targeting Kiss1, Tac2, Pdyn and Kiss1R, Tacr3, Oprk1. Scale bar $20 \mu \mathrm{m}$. e ARN kisspeptin neurons expressing $\mathrm{Ca}^{2+}$ indicator GCaMP and the change in fluorescence intensity from the time-lapse representation of the indicated vertical line. Scale bar $100 \mu \mathrm{m}$. $\mathbf{f}$ Raster plot and quantified graph of $\mathrm{Ca}^{2+}$ oscillation in time-lapse recording for $30 \mathrm{~min}$. The number of analyzed cells are indicated on the left. $\mathbf{g}$ Single peak magnified from the dotted box in (f) for close inspection. AAV, Adeno-associated virus; GFP, green fluorescent protein.

Kisspeptin Neuron-Specific $\mathrm{Ca}^{2+}$

Oscillation in ARN of Neonatal Mice sity according to the depth of imaging positions (online suppl. Fig. S4D). The small cassettes reveal that the intensity decreases in cell \#1, while it is the opposite in cell \#2. This pattern is also depicted in the 3-dimensional image on the right, indicating that the soma of cell $\# 2$ is located at the lower end of the slice, compared to cell \#1 (online suppl. Fig. S4D). The difference in the $Z$-axis location of cell bodies, therefore, could have contributed to the amplitude variation of the $\mathrm{Ca}^{2+}$ intensity of kisspeptin neurons, in addition to varying kinetics [35]. Then, we addressed whether the preparation of ex vivo slice cultures may affect spontaneous synchronicity of ARN kisspeptin population. Similar to coronal slices (Fig. 1e, f), synchronized $\mathrm{Ca}^{2+}$ oscillation was also detected from horizontal slices, though the intensity was less stable over time compared to the coronal sections (online suppl. Fig. S4E), indicating that the oscillation is independent of plane orientation. To observe whether dopaminergic neurons, another ARN population that exhibits synchronized firing, could also show $\mathrm{Ca}^{2+}$ oscillation, the ARN of DAT-IRESCre mice were cultured ex vivo and transduced with $\mathrm{Ca}^{2+}$ indicator in the same experimental scheme with that of Kiss1-IRES-Cre. Unlike kisspeptin neurons, a few number of cells were observed with weak GCaMP signals (online suppl. Fig. S4F).

Also, pan-neuronal $\mathrm{Ca}^{2+}$ oscillation was observed from wild-type organotypic slice cultures transduced with AAV expressing GCaMP under the control of the hSyn promoter. The pattern of $\mathrm{Ca}^{2+}$ concentration fluctuation in pan-neuronal imaging included both irregular, occasionally simultaneous peaks and regular, synchronized peaks (online suppl. Fig. S5A). Approximately two-thirds of neurons exhibited irregular fluctuation of intracellular $\mathrm{Ca}^{2+}$ concentration, and the rest exhibited regular and synchronized $\mathrm{Ca}^{2+}$ oscillation (online suppl. Fig. S5B). Comparing ARN kisspeptin neuron-specific $\mathrm{Ca}^{2+}$ oscillation with pan-neuronal $\mathrm{Ca}^{2+}$ oscillation, individual neurons had varying amplitudes. The oscillation period, on the other hand, was highly synchronized and coherent in kisspeptin neurons with a period of 3.05 $\pm 0.04 \mathrm{~min}$, in contrast to heterogeneous periods in the pan-neuronal population $(41.32 \pm 3.86 \mathrm{~min})$. The number of peaks in the same time period was significantly higher in kisspeptin neurons, altogether demonstrating that ARN kisspeptin neurons specifically exhibit synchronized ultradian $\mathrm{Ca}^{2+}$ rhythmicity (online suppl. Fig. $\mathrm{S} 5 \mathrm{C})$. Taken together, these data demonstrate that ex vivo $\mathrm{Ca}^{2+}$ imaging results are a consistent and reliable method for analyzing the rhythmicity of kisspeptin neurons in real time.

Neuroendocrinology 2020;110:1010-1027 DOI: $10.1159 / 000505922$ 
Fig. 2. Voltage-gated ion channels involved in synchronized $\mathrm{Ca}^{2+}$ oscillation in ARN kisspeptin neurons. a Raster plot and quantified graph of $\mathrm{Ca}^{2+}$ oscillation with vehicle ( $0.02 \%$ sodium acetate in recording media) administration. Experiments were performed on 184 neurons in 4 mice (1 male and 3 females). b Change in fluorescence intensity with administration of voltagegated sodium channel blocker (TTX, 0.5 $\mu \mathrm{M})$. Experiments were performed on 316 neurons in 8 mice ( 3 males and 5 females). c Raster plot and quantified graph of $\mathrm{Ca}^{2+}$ oscillation with vehicle $(0.1 \%$ distilled water in recording media) administration. Experiments were performed on 187 neurons in 4 mice ( 1 male and 3 females). $\mathbf{d}$ Change in fluorescence intensity with administration of voltage-gated potassium channel blocker (4-AP, $0.5 \mathrm{mM}$ ). Experiments were performed on 174 neurons in 5 mice (2 males and 3 females). VEH, vehicle; TTX, tetrodotoxin; 4-AP, 4-aminopyridine.
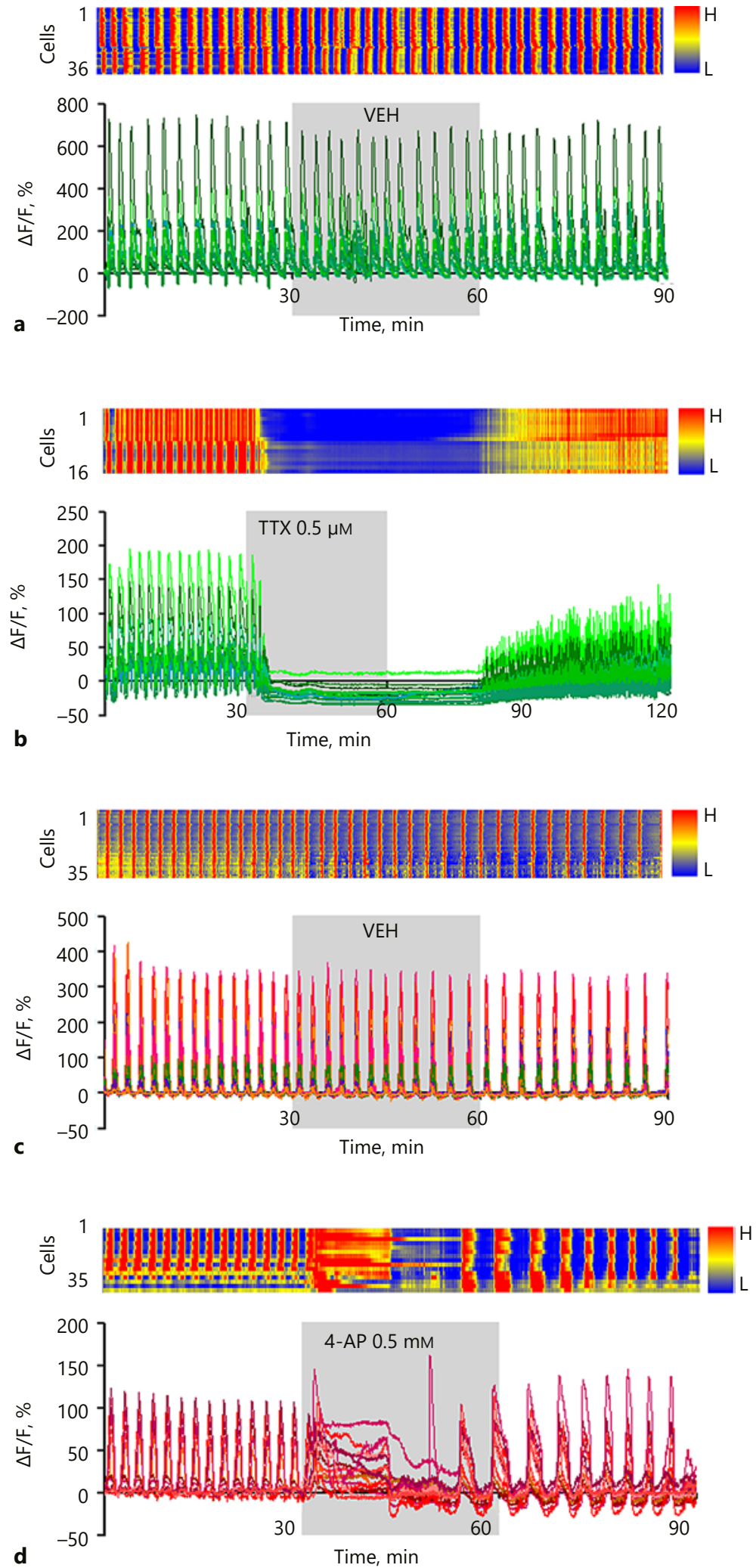
Voltage-Gated Ion Channels Involved in Synchronized $\mathrm{Ca}^{2+}$ Oscillation in ARN Kisspeptin Neurons

To determine whether voltage-gated ion channels are involved in operating the synchronized $\mathrm{Ca}^{2+}$ oscillation of ARN kisspeptin neurons, voltage-gated ion channel blockers were applied to ARN slices ex vivo. TTX is a widely used neurotoxin that binds to voltage-gated sodium channels and inhibits action potential, thereby blocking neuronal transmission without changing the resting potential [36]. The bath application of TTX (0.5 $\mu \mathrm{M}$ ) almost completely abolished the $\mathrm{Ca}^{2+}$ oscillations in kisspeptin neurons compared to vehicle treatment, indicating that action potential generation and propagation are involved in the synchronized rhythm generation (Fig. 2a, b). The $\mathrm{Ca}^{2+}$ oscillation began to diminish a couple of peaks following TTX application (Fig. 2b). The $\mathrm{Ca}^{2+}$ oscillation started to reappear during washout but did not fully recover to the pretreatment level. The recovery from TTX required more incubation time than the posttreatment phase, and the frequencies of $\mathrm{Ca}^{2+}$ oscillation were short with slow increments of amplitude (Fig. 2b). We next applied 4-AP, a voltage-gated potassium channel blocker known to affect action potential duration [37]. When 4-AP $(0.5 \mathrm{mM})$ was applied to ARN, the kisspeptin neuron-specific $\mathrm{Ca}^{2+}$ oscillation was sustained at the peak level without oscillation and gradually returned to baseline and recovered the spontaneous oscillation compared to vehicle (Fig. 2c, d). Noticeably, the oscillatory period after 4-AP treatment was lengthened (Fig. 2d) compared to vehicle (Fig. 2c). Ltype voltage-gated $\mathrm{Ca}^{2+}$ channels are important in hormone secretion and are involved in $\mathrm{GnRH}$ neuron $\mathrm{Ca}^{2+}$ transients $[38,39]$. However, when L-type voltage-gated $\mathrm{Ca}^{2+}$ channels were blocked by verapamil, there was no change in synchronized $\mathrm{Ca}^{2+}$ oscillation (online suppl. Fig. S6A). Oscillation peak interval did not increase by low-voltage-activated or transient (T)-type $\mathrm{Ca}^{2+}$ channels at 2 doses (online suppl. Fig. S6B). To observe whether TeNT administration could alter synchronized $\mathrm{Ca}^{2+}$ oscillations, slices were incubated with $0.25 \mu \mathrm{g}$ of TeNT for $30 \mathrm{~min}$ or $100 \mathrm{ng} / \mathrm{mL}$ for $5 \mathrm{~h}$ [40], but did not exhibit a significant change (online suppl. Fig. S6C). Taken together, these results suggest that action potentials, but not $\mathrm{Ca}^{2+}$ channels or synaptic release mediated in the same scheme as TeNT, are critical for synchronized $\mathrm{Ca}^{2+}$ oscillation in ARN kisspeptin neurons. Since TeNT may act preferentially at inhibitory synapses $[40$, 41], the involvement of glutamatergic transmission cannot be ruled out.

Kisspeptin Neuron-Specific $\mathrm{Ca}^{2+}$

Oscillation in ARN of Neonatal Mice
Regulatory Mechanisms Involved in Synchronized $\mathrm{Ca}^{2+}$ Oscillation in ARN Kisspeptin Neurons

Various drugs are dissolved in different vehicles such as dimethyl sulfoxide in Figure 3a, sodium acetate, distilled water, or methanol in other occasions. There are slight variations in the peak interval between the pre-, treat-, and post-phases even in the vehicle-treated control experiments. The mean values are expressed by the box and whisker plot in Figure 3a. We utilized $\Delta$ peak interval as described in the Statistical Analyses section in the Materials and Methods.

Then, the mechanisms underlying synchronized $\mathrm{Ca}^{2+}$ oscillation in ARN kisspeptin neurons were explored. Synchronized oscillation can be produced via a pacemaker, or arise from collective action among the neurons. In particular, intracellular communication in the hypothalamus includes electrical coupling by gap junctions that mediates intracellular transfer of ions in connected neuronal networks [42]. Thus, the contribution of gap junctional coupling in synchronized $\mathrm{Ca}^{2+}$ oscillations in ARN kisspeptin neurons was addressed. Mefloquine blocks neuronal gap junction composed of $\mathrm{Cx} 36$ and 50 [43]. However, oscillation $\Delta$ peak interval did not increase by mefloquine administration compared to vehicle (Fig. 3b). Another gap junction blocker, oleic acid, that targets Cx43 [44] also failed to change $\mathrm{Ca}^{2+}$ oscillation (Fig. 3c). These results suggest that gap junctions mediated by $\mathrm{Cx} 36,50$, or 43 may not regulate synchronized $\mathrm{Ca}^{2+}$ oscillation at the neonatal stage.

Then, we asked whether internal stores of $\mathrm{Ca}^{2+}$ that regulate $\mathrm{Ca}^{2+}$ homeostasis and signaling, can modulate synaptic plasticity or postsynaptic responses $[45,46]$, and play a role in $\mathrm{Ca}^{2+}$ oscillation of ARN kisspeptin cultures. $\mathrm{IP}_{3}$ receptor is one of major mechanisms by which ER releases $\mathrm{Ca}^{2+}$ [47]. Administration of the ER blocker (heparin, $50 \mu \mathrm{g} / \mathrm{mL})$ significantly $(p<0.001)$ increased $\Delta$ peak interval (Fig. 3d). SERCA transfers $\mathrm{Ca}^{2+}$ from the cytosol to the SR/ER lumen [48]. Administration of the SERCA inhibitor (thapsigargin, $4 \mu \mathrm{M}$ ) increased $\Delta$ peak interval (Fig. 3e). These results suggest that intracellular $\mathrm{Ca}^{2+}$ storage from the ER is a potent regulatory mechanism to establish $\mathrm{Ca}^{2+}$ oscillation.

\section{Chemogenetic Modulation of ARN Kisspeptin}

Neurons Alters Synchronized $\mathrm{Ca}^{2+}$ Oscillation

To examine whether $\mathrm{Ca}^{2+}$ oscillation in ARN kisspeptin neurons is synchronized by action potential propagation between the kisspeptin neuron population, DREADDs $[49,50]$ were used for kisspeptin neuron-specific manipulation. For kisspeptin neuron inhibition, ARN

Neuroendocrinology 2020;110:1010-1027 DOI: $10.1159 / 000505922$ 
Fig. 3. Regulatory mechanisms involved in synchronized $\mathrm{Ca}^{2+}$ oscillation in ARN kisspeptin neurons. a Raster plot and quantified graph of $\mathrm{Ca}^{2+}$ oscillation with $\mathrm{VEH}$ (0.02\% dimethyl sulfoxide in recording media) administration. On the right, the mean values of the 3 phases (pre-, treat-, and post-) in the control experiments are expressed in box and whisker plot. b Change in fluorescence intensity with administration of gap junction blocker mefloquine (selective for Cxs 36 and 50) at 10 $\mu \mathrm{M} . \Delta$ Peak interval in the pre-, treat-, and post-phases are analyzed from 59 neurons in 2 female mice for $\mathrm{VEH}$ and 234 neurons in 6 mice ( 1 male and 5 females) for mefloquine. c Change in fluorescence intensity with administration of gap junction blocker oleic acid (selective for Cxs 32 and 43) at $100 \mu \mathrm{M} . \Delta$ Peak interval in the pre-, treat-, and post-phases are analyzed from 139 neurons in 3 mice ( 1 male and 2 females). d Change in fluorescence intensity with administration of $\mathrm{IP}_{3}$ receptor blocker (heparin, $50 \mu \mathrm{g} / \mathrm{mL}) . \Delta$ Peak interval in the pre-, treat-, and post-phases are analyzed from 141 neurons in 4 mice ( 1 male and 3 females). e Change in fluorescence intensity with administration of SERCA blocker (thapsigargin, $4 \mu \mathrm{M}$ ). $\Delta$ Peak interval in the pre-, treat-, and post-phases are analyzed from 328 neurons in 7 mice $(3$ males and 4 females). ${ }^{* * *} p<0.001$ compared to prephase and ${ }^{\dagger \dagger \dagger} p<0.001$ compared to treatphase. VEH, vehicle; TG, thapsigargin.
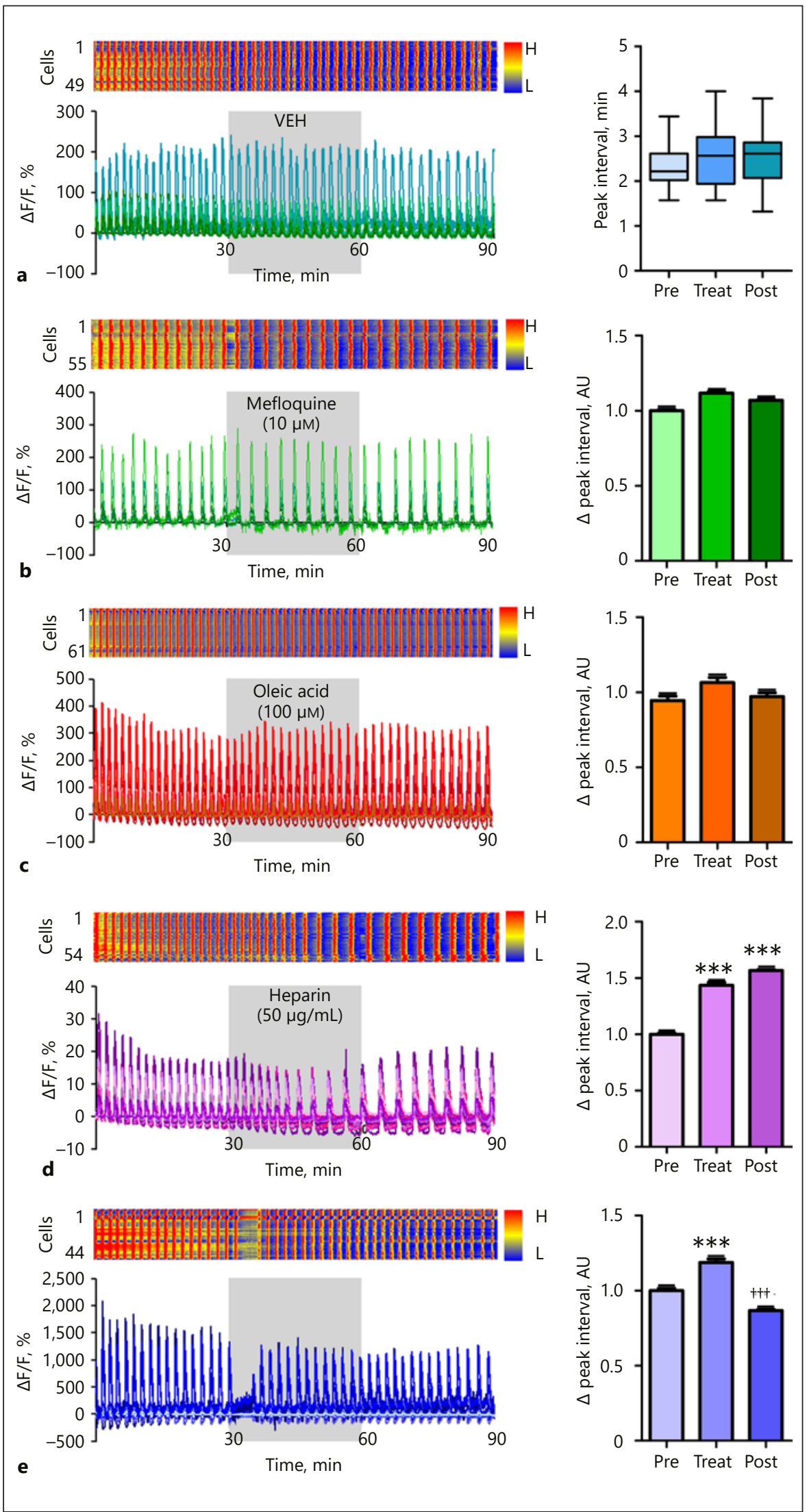
slice cultures derived from Kiss1-IRES-Cre were sequentially transduced with AAV expressing GCaMP6m and hM4Di-mCherry in a kisspeptin neuron-specific manner (online suppl. Fig. S7A). ARN kisspeptin neurons showed positive signals for both GCaMP and hM4DimCherry after transduction (Fig. 4a). The percentages of GCaMP $6 \mathrm{~m}^{+}$, mCherry ${ }^{+}$, and GCaMP $6 \mathrm{~m}^{+} / \mathrm{mCherry}^{+}$ double-positive kisspeptin neurons are shown in Figure $4 \mathrm{~b}$, and the proportions of double-positive neurons in the GCaMP $6 \mathrm{~m}^{+}$or mCherry ${ }^{+}$population are also shown in Figure 4b. Approximately 24\% of GCaMP6m-positive kisspeptin neurons were positive for mCherry, while $63 \%$ of mCherry-positive neurons were positive for GCaMP6m (Fig. $4 \mathrm{~b})$. When the DREADD ligand CNO $(1 \mu \mathrm{M})$ was applied to ARN kisspeptin neurons, $\mathrm{Ca}^{2+}$ oscillation dampened (Fig. 4c) while vehicle treatment produced no effect (online suppl. Fig. S7B). Notice that there are different patterns of oscillation from the populations on the left and right side of the third ventricle, $3 \mathrm{~V}$ (Fig. 4c). This difference is thought to originate from loss of connection with the contralateral side as the neurons were cultured ex vivo. The synchronized oscillation is maintained within the ipsilateral region. Approximately one-fourth of GCaMP-positive ARN kisspeptin neurons were mCherry-positive, yet the synchronized $\mathrm{Ca}^{2+}$ oscillation in all GCaMP-positive kisspeptin neurons was inhibited by CNO (Fig. 4c), suggesting that transmission from hM4Di-positive kisspeptin neurons can inhibit the rest of the population. Nevertheless, $\mathrm{Ca}^{2+}$ oscillation resumed early even before washout (Fig. 4c), indicating that transmission from hM4Di-negative kisspeptin neurons was sufficient to restore the synchronized $\mathrm{Ca}^{2+}$ oscillation. The peak intensity and interval of oscillation significantly $(p<0.001)$ reduced and increased, respectively, after CNO-induced inhibition (Fig. 4c).

For the activation of kisspeptin neurons, hM3DqmCherry was expressed similarly. When CNO was applied to ARN slices, the baseline of kisspeptin neuron-specific $\mathrm{Ca}^{2+}$ oscillation increased compared to pretreatment (Fig. 4d). Since kisspeptin neurons have an endogenous rhythm, we think that overactivation caused the increased baseline of $\mathrm{Ca}^{2+}$ oscillation. Interestingly, the amplitude significantly $(p<0.001)$ decreased despite the increased baseline, while the $\Delta$ peak interval did not change (Fig. 4d and online suppl. Fig. S7C). The fold change of baseline increase after $\mathrm{CNO}$-induced activation was evaluated for individual ARN kisspeptin neurons (online suppl. Fig. S7D). Among 23 neurons from 1 mouse, the baseline of 10 neurons increased above average, whereas that of 13 neurons barely increased (on-

Kisspeptin Neuron-Specific $\mathrm{Ca}^{2+}$

Oscillation in ARN of Neonatal Mice line suppl. Fig. S7D). Interestingly, both mCherry-positive and -negative neurons responded to $\mathrm{CNO}$ in the DREADD experiment (online suppl. Fig. S7E). Although the absence of mCherry expression does not confirm the absence of functional DREADD, all GCaMP-positive neurons responded with a similar pattern. These results suggest that network activity including ARN kisspeptin neurons contributes to generating synchronized $\mathrm{Ca}^{2+}$ oscillation.

\section{Effect of KNDy Components on ARN Kisspeptin}

Neuron-Specific $\mathrm{Ca}^{2+}$ Oscillations

ARN kisspeptin neurons are also known as KNDy neurons as they coexpress the neuropeptides kisspeptin, $\mathrm{NKB}$, and Dyn, possibly forming an auto-regulatory network [10]. To examine whether these neuropeptides released from KNDy neurons could mediate the synchronized $\mathrm{Ca}^{2+}$ oscillation, we treated the ARN slices with kisspeptin, NK3R agonist (Senk), and Dyn, as well as their antagonists. When ARN slices were administered with kisspeptin, $\mathrm{Ca}^{2+}$ oscillation was briefly suppressed (Fig. 5a). Although ARN kisspeptin neurons do not express Kiss1R, other ARN neuronal populations expressing Kiss1R, such as proopiomelanocortin (POMC) neurons [51] may mediate the kisspeptin-elicited response. We hypothesized that controlling signal transduction via NK3R could contribute to generating the $\mathrm{Ca}^{2+}$ oscillation. However, administration of NK3R antagonist (SB222200, $6 \mu \mathrm{M}$ ) did not increase $\Delta$ peak interval (Fig. 5b). Further, high concentration and short-term administration of Senk (200 nM) did not reduce $\mathrm{Ca}^{2+}$ oscillation $\Delta$ peak interval in kisspeptin neurons (Fig. 5c), and longer administration of Senk at lower dose $(20 \mathrm{nM})$ did not reduce $\Delta$ peak interval (online suppl. Fig. S8A). Dyn administration did not inhibit $\mathrm{Ca}^{2+}$ oscillation while KOR antagonist (nor-BNI, $1 \mu \mathrm{M}$ ) did not reduce $\Delta$ peak interval (Fig. 5d, e). Similarly, longer administration of Dyn at lower dose (100 nM) also did not increase $\Delta$ peak interval (online suppl. Fig. S8B). These results suggest that neuropeptides secreted from ARN kisspeptin neurons have a marginal effect on $\mathrm{Ca}^{2+}$ oscillations at the neonatal stage.

\section{Glutamatergic and GABAergic Effects in ARN}

Kisspeptin Neuron-Specific $\mathrm{Ca}^{2+}$ Oscillation

Electrophysiological properties of ARN kisspeptin neurons can be modulated by excitatory or inhibitory synaptic transmission. For example, ARN kisspeptin neurons could generate burst firing in an NMDA receptor-dependent manner [52], whereas $\mathrm{GABA}_{\mathrm{A}}$ receptormediated inhibitory inputs affected postsynaptic currents 

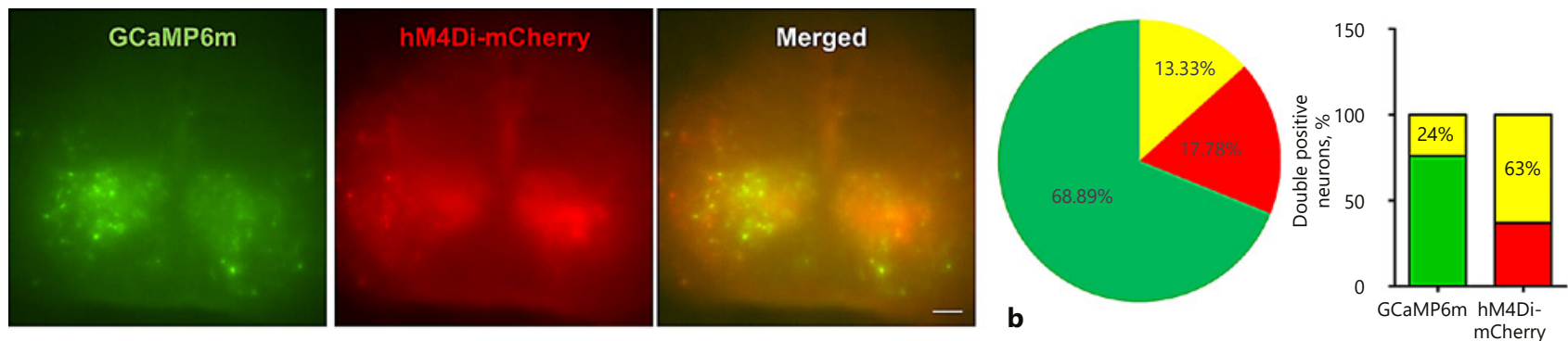

hM4Di

CNO $(1 \mu \mathrm{M})$
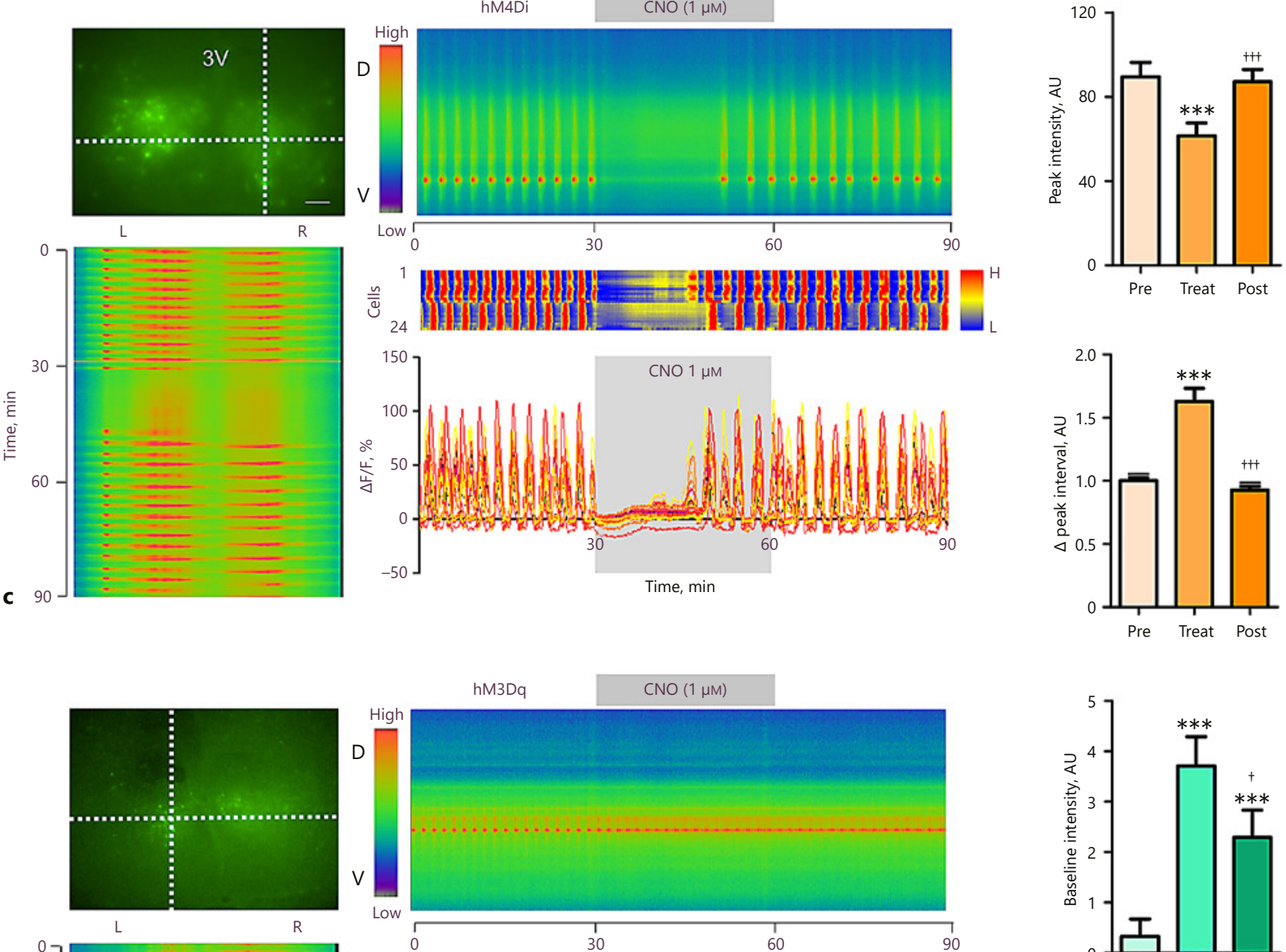

hM3Dq
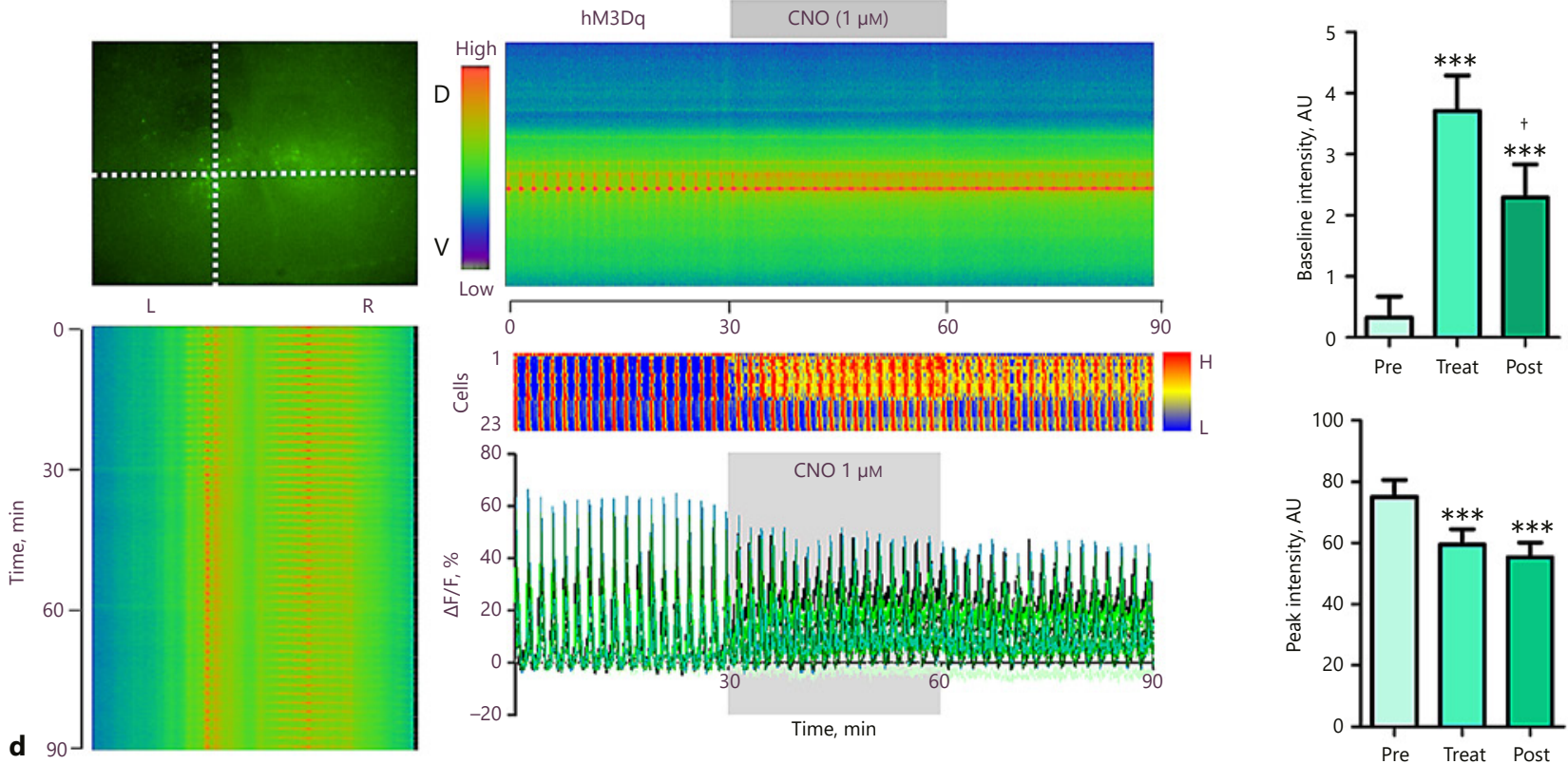

(For legend see next page.) 
[53]. Based on these previous studies, we examined whether NMDA receptor- or $\mathrm{GABA}_{\mathrm{A}}$ receptor-dependent inputs into ARN kisspeptin neurons can affect the synchronized $\mathrm{Ca}^{2+}$ oscillation. Administration of NMDA receptor antagonist, D-AP5 $(50 \mu \mathrm{M})$ to ARN organotypic slices immediately silenced $\mathrm{Ca}^{2+}$ oscillation in kisspeptin neurons (Fig. 6a). After washout, the suppressed $\mathrm{Ca}^{2+}$ oscillation was released within a few minutes and the synchronized oscillation was resumed. Notice the different patterns of oscillation from the populations on the left and right of $3 \mathrm{~V}$ (Fig. 4a). Compared to the pretreatment phase, the peak intensity and the number of peaks were significantly $(p<0.001)$ reduced during the treatment phase (Fig. 6a). The peak intensity and the number of peaks significantly $(p<0.001)$ increased compared to the treatment phase after washout. By administration of the $\mathrm{GABA}_{\mathrm{A}}$ receptor antagonist bicuculline $(10 \mu \mathrm{M}), \Delta$ peak interval temporally increased (Fig. 6b). Interestingly, the peak intensity decreased, and $\Delta$ peak interval significantly $(p<0.001)$ increased (Fig. 6b). This pattern was similar when neurons were treated for 15 or $30 \mathrm{~min}$. These data indicate that both $\mathrm{NMDA}$ and $\mathrm{GABA}_{\mathrm{A}}$ receptor-mediated synaptic transmissions have modulatory actions in kisspeptin neuron-specific $\mathrm{Ca}^{2+}$ oscillations.

\section{Discussion}

This study demonstrated that ARN kisspeptin neurons in neonatal organotypic brain slice cultures exhibit self-sustained, synchronized $\mathrm{Ca}^{2+}$ oscillation. Voltagegated sodium and potassium channels contributed to reg-

Fig. 4. Chemogenetic modulation of ARN kisspeptin neurons alters synchronized $\mathrm{Ca}^{2+}$ oscillation. a Image of kisspeptin neurons expressing Flex-GCaMP and hM4Di-mCherry. Scale bar $200 \mu \mathrm{m}$. b Percentage of kisspeptin neurons expressing GCaMP, mCherry, or both. Percentage of double positive neurons in respect of each GCaMP and mCherry. c Representative image and change in fluorescence intensity of the indicated horizontal and vertical lines with CNO $(1 \mu \mathrm{M})$ administration to inhibitory DREADD (hM$4 \mathrm{Di}$ ). Raster plot and quantified graph of $\mathrm{Ca}^{2+}$ oscillation are also shown. Peak intensity and $\Delta$ peak interval in the pre-, treat-, and post-phases are analyzed from 56 neurons in 2 mice ( 1 male and 1 female). $\mathbf{d}$ Representative image and change in fluorescence intensity of the indicated horizontal and vertical lines for activation (hM3Dq). Raster plot and quantified change in $\mathrm{Ca}^{2+}$ oscillation are also shown. Baseline intensity and peak interval in the pre-, treat-, and post-phases are analyzed from 62 neurons in 2 females, ${ }^{* * *} p$ $<0.001$ compared to pre-phase and ${ }^{\dagger \dagger \dagger} p<0.001,{ }^{\dagger} p<0.05$ compared to treat-phase. $\mathrm{CNO}$, clozapine- $\mathrm{N}$-oxide.

Kisspeptin Neuron-Specific $\mathrm{Ca}^{2+}$

Oscillation in ARN of Neonatal Mice ulating the synchronized oscillation in ARN kisspeptin neurons, indicating that the action potential is involved in generating synchronous $\mathrm{Ca}^{2+}$ oscillations. Also, intracellular $\mathrm{Ca}^{2+}$ regulation from the ER appears to be a potent regulatory mechanism to maintain the oscillations. Chemogenetic modulation of ARN kisspeptin neurons revealed that a network within the ARN kisspeptin neuronal population is involved in mediating the synchronized oscillations, although signaling through NK3R or KOR marginally influenced $\mathrm{Ca}^{2+}$ oscillations. We also observed that both NMDA and $\mathrm{GABA}_{\mathrm{A}}$ receptor-dependent signaling contributed to maintaining the synchronized $\mathrm{Ca}^{2+}$ oscillation in ARN kisspeptin neurons. This study demonstrated, for the first time, that synchronized $\mathrm{Ca}^{2+}$ oscillation is present in ARN kisspeptin neurons in the neonatal stage ex vivo.

Synchronized oscillations can be produced via a pacemaker or arise from collective action among neurons. In the present study, oscillation $\Delta$ peak interval of ARN kisspeptin neurons did not increase by gap junction blockers mefloquine and oleic acid. A recent study reported that mefloquine inhibited $\mathrm{Ca}^{2+}$ oscillations in Kiss1-GFP cells from the embryonic day 17-18 primary culture, but Cx36 mRNA was not detected in adult Kiss1-GFP transgenic mice [54]. Based on our results and the previous studies, it is difficult to clarify whether gap junctions mediate the synchronized $\mathrm{Ca}^{2+}$ oscillation across all stages of development, especially in ARN kisspeptin neurons in explant culture derived from neonatal mice. Further, inhibition of $\mathrm{Ca}^{2+}$ oscillation by TTX and D-AP5 imply that neural transmission, especially signaling through NMDA receptors, is essential to maintain synchronized $\mathrm{Ca}^{2+}$ oscillation in ARN kisspeptin neurons. Meanwhile, $\mathrm{IP}_{3}$ receptor blocker and SERCA inhibitor increased $\Delta$ peak intervals, suggesting that intracellular $\mathrm{Ca}^{2+}$ regulation from the ER is a potent regulatory mechanism to establish $\mathrm{Ca}^{2+}$ oscillation during the neonatal period.

The DREADD system employs $G$ protein-coupled receptor signaling, while optogenetics opens ion channels to control neural activity [55]. Clarkson et al. [11] used optogenetic archaerhodopsin-mediated silencing of ARN kisspeptin neurons and observed a reduced firing rate in ARN kisspeptin neurons and a decrease in LH pulse frequency and amplitude. Their results are in line with the present DREADD experiment, but the synthetic ligand CNO may exhibit a stronger inhibition when directly applied to brain slices, compared to optogenetic inhibition. Inhibition in vivo requires bilateral targeting that needs to be passed on from kisspeptin to GnRH neurons, and onto gonadotropes in the anterior pituitary. Therefore,

Neuroendocrinology 2020;110:1010-1027 DOI: $10.1159 / 000505922$ 
Fig. 5. Effect of KNDy components on ARN kisspeptin neuron-specific $\mathrm{Ca}^{2+}$ oscillations. a Raster plot and quantified graph of $\mathrm{Ca}^{2+}$ oscillation with kisspeptin $(\mathrm{Kp}, 20 \mathrm{nM})$ administration. $\Delta$ Peak interval in the pre-, treat-, and post-phases are analyzed from 106 neurons in 3 mice (1 male and 2 females). b Raster plot and quantified graph of $\mathrm{Ca}^{2+}$ oscillation with NK3R antagonist (SB222200, $6 \mu \mathrm{M}$ ) administration. $\Delta$ Peak interval in the pre-, treat-, and post-phases are analyzed from 217 neurons from 5 mice $(2$ males and 3 females). c Raster plot and quantified graph of $\mathrm{Ca}^{2+}$ oscillation with NK3R agonist Senk $(200 \mathrm{nM})$ administration. $\Delta$ Peak interval in the pre-, treat-, and post-phases are analyzed from 239 neurons from 5 mice (3 males and 2 females). d Raster plot and quantified graph of $\mathrm{Ca}^{2+}$ oscillation with Dyn (400 nM) administration. $\Delta$ Peak interval in the pre-, treat-, and post-phases are analyzed from 213 neurons from 4 mice ( 2 males and 2 females). e Raster plot and quantified graph of $\mathrm{Ca}^{2+}$ oscillation with KOR antagonist (nor-BNI, $1 \mu \mathrm{M}$ ) administration. $\Delta$ Peak interval in the pre-, treat-, and post-phases are analyzed from 179 neurons from 3 mice $(1$ male and $2 \mathrm{fe}$ males). ${ }^{* * *} p<0.001$ compared to prephase. Senk, senktide; Dyn, dynorphin.
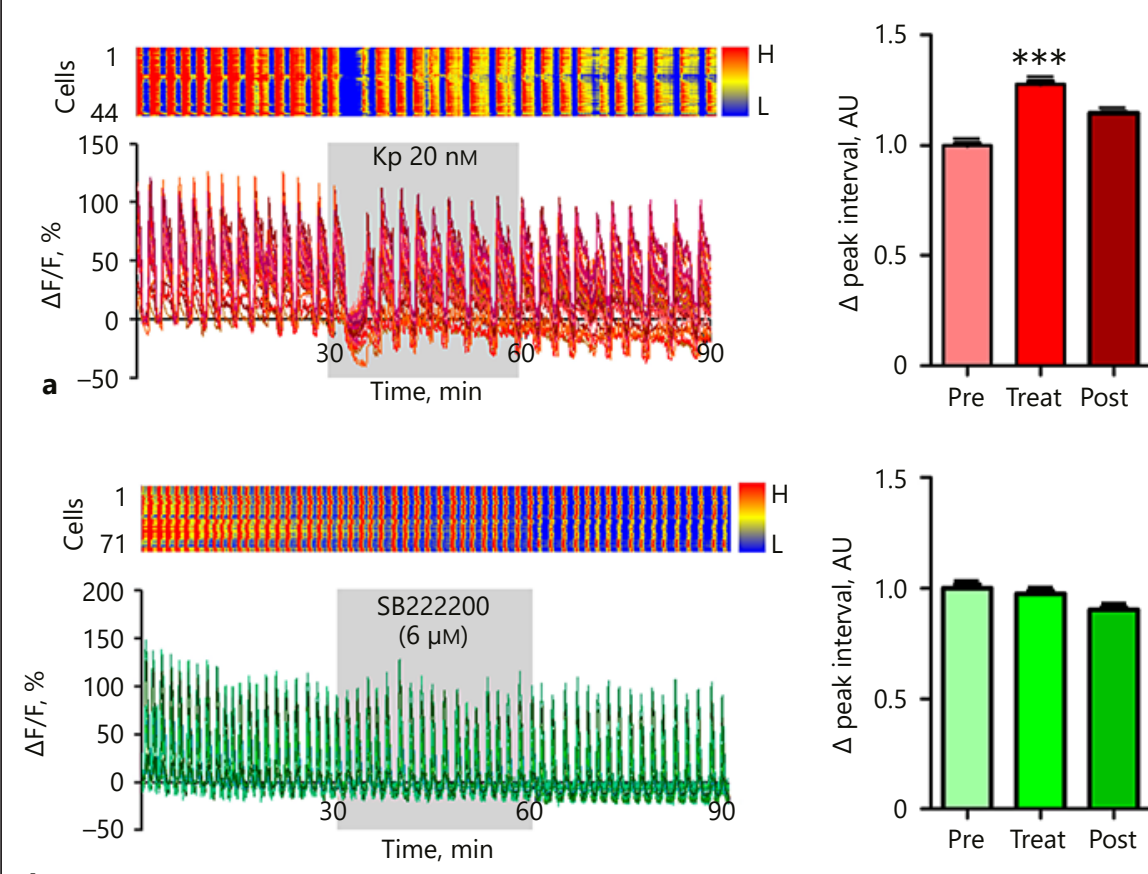

b
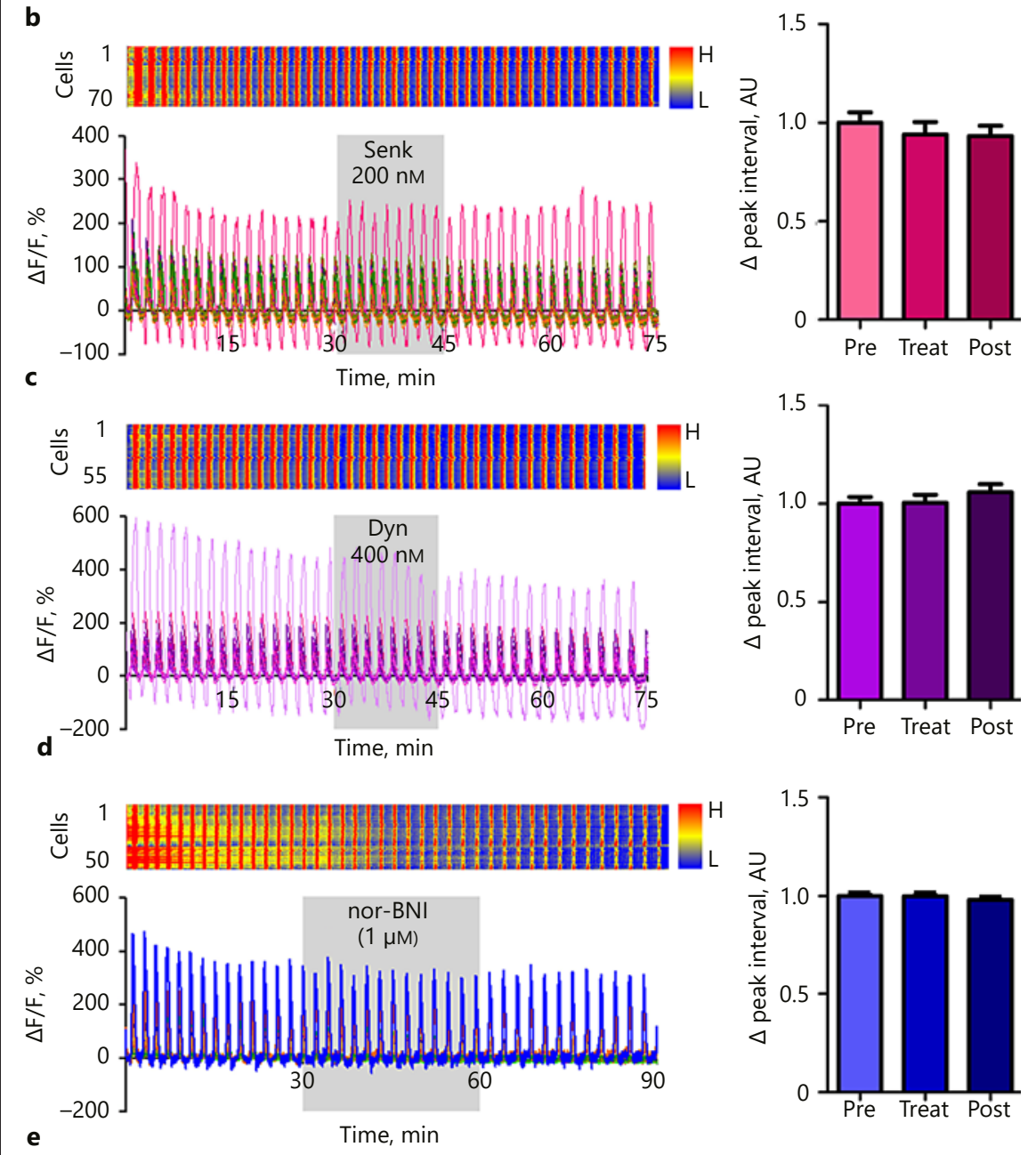


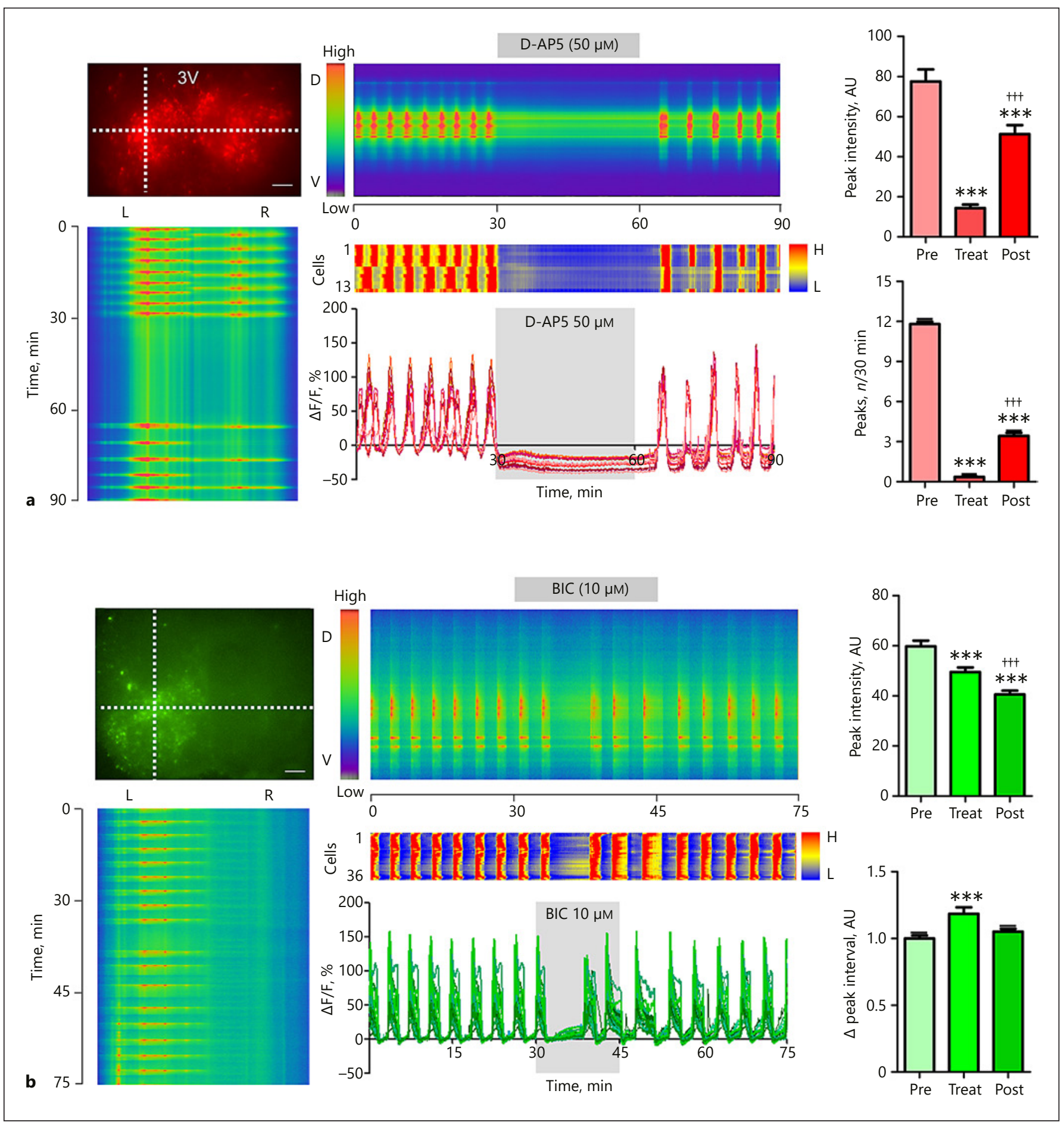

Fig. 6. Glutamatergic and GABAergic effects in ARN kisspeptin neuron-specific $\mathrm{Ca}^{2+}$ oscillation. a Representative image and change in fluorescence intensity from the time-lapse representation of the indicated vertical line with NMDA receptor antagonist $(\mathrm{D}-\mathrm{AP} 5,50 \mu \mathrm{M})$ application. Scale bar $200 \mu \mathrm{m}$. Raster plot and quantified graph of $\mathrm{Ca}^{2+}$ oscillation are also shown. Peak intensity and number of peaks during the pre-, treat-, and post-phases are analyzed from 153 neurons in 5 mice ( 2 males and 3 females). b Representative image and change in fluorescence intensity of the indicated horizontal and vertical lines with $\mathrm{GABA}_{\mathrm{A}}$ receptor antagonist (BIC, $10 \mu \mathrm{M}$ ) administration. Scale bar $200 \mu \mathrm{m}$. $\Delta$ Peak intensity and interval of $\mathrm{Ca}^{2+}$ oscillation in pre-, treat-, and postphases are analyzed from 299 neurons in 8 mice ( 4 males and 4 females, ${ }^{* * *} p<0.001$ compared to pre-phase and ${ }^{\dagger \dagger \dagger} p<0.001$ compared to treat-phase). BIC, bicuculline. 
real-time $\mathrm{Ca}^{2+}$ readout provides an efficient method to observe direct changes after manipulation.

Synchronized $\mathrm{Ca}^{2+}$ oscillation in ARN kisspeptin neurons is essential for the continuous local neuronal transmission, as revealed by the DREADD system. This result suggests that the inputs within ARN kisspeptin neurons could be involved in generating the synchronized $\mathrm{Ca}^{2+}$ oscillation. The observation that kisspeptin administration inhibited $\mathrm{Ca}^{2+}$ oscillation was interesting, since ARN kisspeptin neurons do not express Kiss1R. Hence, a non-kisspeptin population expressing Kiss1R in the ARN was considered, given that the hypothalamic ARN is involved in numerous physiological functions and is composed of diverse cell types, as revealed by single-cell RNA-seq technology [56]. For instance, kisspeptin can excite or inhibit POMC or neuropeptide Y (NPY) neurons, respectively, while NPY, gonadotropin-inhibiting hormone, and RFamide-related peptide 3 receptor (RFRP-3) can inhibit POMC cells and weaken kisspeptin excitation [57]. There are also reports on RFRP-3 expression in the mouse ARN [58], suggesting the possible source of inhibition after kisspeptin treatment. Therefore, while kisspeptin neurons do not express Kiss1R, it is probable that kisspeptin administration acted on other populations in the ARN, that is, NPY, gonadotropininhibiting hormone, or RFRP-3, that can inhibit ARN kisspeptin neurons. Previous studies reported that NKB stimulated, while Dyn inhibited ARN kisspeptin neuron activity [10]. In the present study, manipulating NK3R or KOR had marginal effects on the synchronized $\mathrm{Ca}^{2+}$ oscillations in neonatal ARN kisspeptin neurons. Indeed, from the FISH data, the levels of receptors expressed in neonatal slices were low. There are studies reporting expression of Tac2 and Tacr3 increase with postnatal maturation $[59,60]$. Based on the results in the present study and the above studies, the KNDy system may not be fully developed at this point to be completely functional. In the meantime, it is interesting that synchronized $\mathrm{Ca}^{2+}$ oscillations in ARN kisspeptin neurons were present early on from the neonatal stage, without NKB and Dyn regulation. Since NKB and Dyn participate in mediating oscillations of neural activity [61], the present study suggests that kisspeptin neurons can generate autonomous oscillation in the absence of full development. Once the activity of NKB and Dyn in ARN kisspeptin neurons takes place in the later stages of development, oscillation frequency could reshape [62].

Recently, ARN kisspeptin neurons were reported to exhibit synchronized $\mathrm{Ca}^{2+}$ oscillations with a period of approximately $9 \mathrm{~min}$ using fiber photometry in adult mice in vivo [11]. In fact, there is plenty of potential that the $\mathrm{Ca}^{2+}$ oscillation could reshape during the developmental stages. First, as mentioned above, the auto-regulation of KNDy neurons is acquired at later stages of development. Second, when gonadal steroid input was abolished by gonadectomy in male mice, the $\mathrm{Ca}^{2+}$ episode became more frequent over time [63]. Therefore, it is plausible that the ARN kisspeptin neuronal population may become mature alongside the sexual development established steroid milieu. Third, kisspeptin neurons in the AVPV are first expressed at postnatal day 25 [6], and the innervation between AVPV and ARN kisspeptin neurons is observed in 2-4 month male and female mice [64]. It is quite probable that maturation and communication between the 2 regional populations in adult mice alter the regulation of ARN neurons compared to the neonatal state. Even in downstream GnRH neurons, $\mathrm{Ca}^{2+}$ oscillations [65] and the frequency of GnRH secretion [66] change over development. Thus, the present study suggests that ARN kisspeptin neurons can organize their ultradian rhythm, which can be tuned with regulatory inputs along with the developmental processes.

Although administration of TeNT did not alter the synchronized $\mathrm{Ca}^{2+}$ oscillation, inhibition of NMDA receptor with D-AP5 immediately suppressed the $\mathrm{Ca}^{2+}$ oscillation in a transient manner. There are reports that TeNT selectively acts on inhibitory synapses [40, 41]. Notably, approximately $90 \%$ of ARN kisspeptin neurons express mRNAs that encodes for vesicular glutamate transporter 2, which reflects excitatory neurons that release glutamate [67]. In a previous study, the injection of the NMDA receptor antagonist MK801 injected to ewes for 4 hours had no significant effect on the LH pulse pattern [68]. One advantage of imaging intracellular $\mathrm{Ca}^{2+}$ variations is that the antagonist can access kisspeptin neurons directly through the bath application and cause and immediate response, similar to whole-cell recordings where NMDA induces burst firing activity [52]. Therefore, blocking the NMDA receptor may not be sufficient to completely inhibit the downstream LH pulse in vivo. In another study, when ARN kisspeptin neurons were stimulated, the glutamatergic fast excitatory postsynaptic potential was detected in the contralateral side [69]. Based on our results and other studies, it may be concluded that glutamatergic transmission mediated by NMDA receptors in ARN kisspeptin neurons could be involved in modulating the synchronized $\mathrm{Ca}^{2+}$ oscillation. On the contrary, GABA application to adult ARN slices silenced the firing of kisspeptin neurons in a previous study [52]. Yet, in another study, activation of GA- 
$\mathrm{BA}_{\mathrm{A}}$ receptors depolarized the membrane potential of ARN kisspeptin neurons [53]. Also, GABA, though generally accepted as an inhibitory transmitter, can exert excitatory actions in immature neurons with higher intracellular chloride ion concentrations, then gradually switch to inhibitory action in the course of development [70]. This GABAergic regulation on the synchronized $\mathrm{Ca}^{2+}$ oscillation of ARN kisspeptin neurons has a potential origin in the ARN region. Most of the agouti-related peptide/NPY neurons in the ARN are reported as GABAergic neurons [71]. ARN kisspeptin neurons arise from Pomc-expressing progenitors, along with POMC and agouti-related peptide/NPY neurons that have an antagonistic function in regulating energy homeostasis, suggesting a possible link between nutrition-sensing and reproductive development [72].

Kisspeptin neurons are known to be important regulators in the GnRH pulse generator. In the previous studies, $\mathrm{GnRH}$ neurons exhibited approximately $8 \mathrm{~s}$ of $\mathrm{Ca}^{2+}$ transients recorded in acute slices of PeriCam, a transgenic mouse line expressing a genetically encodable $\mathrm{Ca}^{2+}$ indicator [39], whereas the GnRH pulsatility in secretion was at least $20 \mathrm{~min}$ in GT1 cells as well as in the ex vivo median eminence superfusion [73, 74]. Moreover, for optogenetic manipulation of GnRH neurons, $10 \mathrm{~Hz}$ stimulation for 2 min was sufficient to generate LH pulses [18]. These studies imply that there are differences in the temporal dimensions of the $\mathrm{Ca}^{2+}$ activity exhibited in $\mathrm{GnRH}$ neurons, the pulsatile secretion of $\mathrm{GnRH}$, and the stimulus required to activate $\mathrm{GnRH}$ neurons. It is also challenging to relate the pulsatile rhythm of $\mathrm{GnRH}$ neurons with the $\mathrm{Ca}^{2+}$ oscillation with an approximately $3 \mathrm{~min}$ period observed in neonatal ARN kisspeptin neurons. Therefore, the relation between the spontaneous $\mathrm{Ca}^{2+}$ oscillation of the ARN kisspeptin neurons and the pulsatile rhythm in $\mathrm{GnRH}$ neurons requires further exploration. To elucidate the role of the ARN kisspeptin neuronal $\mathrm{Ca}^{2+}$ oscillations in the GnRH pulse generator, it will be necessary to investigate the relation of ARN kisspeptin neuronspecific $\mathrm{Ca}^{2+}$ oscillation with kisspeptin and $\mathrm{GnRH}$ secretion.

In summary, our study demonstrated that ARN kisspeptin neurons in neonatal organotypic slice culture can generate a self-sustained and synchronized ultradian rhythm ex vivo. The ARN kisspeptin neuron-specific $\mathrm{Ca}^{2+}$ oscillation was regulated by intra-ARN inputs, including ARN kisspeptin neurons, suggesting that the ARN kisspeptin neurons can maintain synchronous oscillation of neural activity in the absence of upstream input from other brain regions during the early neonatal period. In the future, it would be important to understand whether the self-sustained $\mathrm{Ca}^{2+}$ oscillation observed in the neonatal explant culture is relevant to in vivo oscillation of ARN kisspeptin activity, and thus to the activity of the GnRH pulse generator.

\section{Acknowledgments}

The authors would like to thank Dr. Massimiliano Beltramo and Dr. Alain Caraty for the Kisspeptin antiserum and Prof. Ulrich Boehm for Kiss1-IRES-Cre mice.

\section{Statement of Ethics}

The authors have no ethical conflicts to disclose.

\section{Disclosure Statement}

The authors have no conflicts of interest to declare.

\section{Funding Sources}

This work was supported by the Ministry of Science, ICT and Future Planning through the National Research Foundation of Korea (NRF-2017R1A2A1A05001351) and Daegu Gyeongbuk Institute of Science and Technology Start-up Fund Program (2019010078).

\section{Author Contributions}

D.K. designed and carried out the experiments under the supervision of H.K.C. and K.K. S.J. performed immunohistochemistry and counting. K.K. contributed to data analysis. M.C. helped sample preparation. J.K. and I.P. aided in result interpretation. S.L., W.D.H., and G.H.S. contributed to the design and implementation of the research. H.K.C. aided in result interpretation and consulted the project. K.K. supervised the project. D.K. wrote the manuscript in consultation with K.K. All authors commented on the manuscript.

\section{References}

1 Skorupskaite K, George JT, Anderson RA. The kisspeptin-GnRH pathway in human reproductive health and disease. Hum Reprod Update. 2014 Jul-Aug;20(4):485-500.

2 Prevot V. Puberty in mice and rats. Knobil and Neill's Physiology of Reproduction New York. Elsevier; 2015. pp. 1395-439.

3 Herbison AE. Control of puberty onset and fertility by gonadotropin-releasing hormone neurons. Nat Rev Endocrinol. 2016 Aug; 12(8):452-66. 
4 Keen KL, Wegner FH, Bloom SR, Ghatei MA, Terasawa E. An increase in kisspeptin-54 release occurs with the pubertal increase in luteinizing hormone-releasing hormone-1 release in the stalk-median eminence of female rhesus monkeys in vivo. Endocrinology. 2008 Aug;149(8):4151-7.

5 Kumar D, Periasamy V, Freese M, Voigt A, Boehm U. In utero development of kisspeptin/GnRH neural circuitry in male mice. Endocrinology. 2015 Sep;156(9):3084-90.

6 Clarkson J, Herbison AE. Postnatal development of kisspeptin neurons in mouse hypothalamus; sexual dimorphism and projections to gonadotropin-releasing hormone neurons. Endocrinology. 2006 Dec;147(12):5817-25.

7 Putteeraj M, Soga T, Ubuka T, Parhar IS. A "Timed" Kiss Is Essential for Reproduction: Lessons from Mammalian Studies. Front Endocrinol (Lausanne). 2016 Aug;7:121.

8 Seminara SB, Messager S, Chatzidaki EE, Thresher RR, Acierno JS Jr, Shagoury JK, et al. The GPR54 gene as a regulator of puberty. N Engl J Med. 2003 Oct;349(17):1614-27.

9 Millar RP. New developments in kisspeptin, neurokinin B and dynorphin A regulation of gonadotropin-releasing hormone pulsatile secretion. Neuroendocrinology. 2014;99(1):5-6.

10 Moore AM, Coolen LM, Porter DT, Goodman RL, Lehman MN. KNDy cells revisited. Endocrinology. 2018 Sep;159(9):3219-34.

11 Clarkson J, Han SY, Piet R, McLennan T, Kane GM, Ng J, et al. Definition of the hypothalamic GnRH pulse generator in mice. Proc NatlAcadSciUSA.2017Nov;114(47):E1021623.

12 Padilla SL, Perez JG, Ben-Hamo M, Johnson CW, Sanchez RE, Bussi IL, et al. Kisspeptin neurons in the arcuate nucleus of the hypothalamus orchestrate circadian rhythms and metabolism. Curr Biol. 2019 Feb;29(4):592604.e4.

13 Herbison AE. The gonadotropin-releasing hormone pulse generator. Endocrinology. 2018 Nov;159(11):3723-36.

14 McCartney CR, Marshall JC. Neuroendocrinology of Reproduction. In: Strauss JF, Barbieri RL, editors. Yen \& Jaffe's Reproductive Endocrinology. 7th ed. Philadelphia: Elsevier Saunders; 2014. pp. 3-26.

15 Belchetz PE, Plant TM, Nakai Y, Keogh EJ, Knobil E. Hypophysial responses to continuous and intermittent delivery of hypopthalamic gonadotropin-releasing hormone. Science. 1978 Nov;202(4368):631-3.

16 Wetsel WC, Valença MM, Merchenthaler I, Liposits Z, López FJ, Weiner RI, et al. Intrinsic pulsatile secretory activity of immortalized luteinizing hormone-releasing hormone-secreting neurons. Proc Natl Acad Sci USA. 1992 May;89(9):4149-53.

17 Choe HK, Kim HD, Park SH, Lee HW, Park JY, Seong JY, et al. Synchronous activation of gonadotropin-releasing hormone gene transcription and secretion by pulsatile kisspeptin stimulation. Proc Natl Acad Sci USA. 2013 Apr;110(14):5677-82.
18 Campos P, Herbison AE. Optogenetic activation of GnRH neurons reveals minimal requirements for pulsatile luteinizing hormone secretion. Proc Natl Acad Sci USA. 2014 Dec; 111(51):18387-92.

19 Han SY, McLennan T, Czieselsky K, Herbison AE. Selective optogenetic activation of arcuate kisspeptin neurons generates pulsatile luteinizing hormone secretion. Proc Natl Acad Sci USA. 2015 Oct;112(42):13109-14.

20 Grienberger C, Konnerth A. Imaging calcium in neurons. Neuron. 2012 Mar;73(5):862-85.

21 Terasawa E, Schanhofer WK, Keen KL, Luchansky L. Intracellular $\mathrm{Ca}(2+)$ oscillations in luteinizing hormone-releasing hormone neurons derived from the embryonic olfactory placode of the rhesus monkey. J Neurosci. 1999 Jul;19(14):5898-909.

22 Jasoni CL, Romanò N, Constantin S, Lee K, Herbison AE. Calcium dynamics in gonadotropin-releasing hormone neurons. Front Neuroendocrinol. 2010 Jul;31(3):259-69.

23 Wu YE, Enoki R, Oda Y, Huang ZL, Honma KI, Honma S. Ultradian calcium rhythms in the paraventricular nucleus and subparaventricular zone in the hypothalamus. Proc Natl Acad Sci USA. 2018 Oct;115(40):E9469-78.

24 Humpel C. Organotypic brain slice cultures: A review. Neuroscience. 2015 Oct;305:86-98.

25 Mayer C, Acosta-Martinez M, Dubois SL, Wolfe A, Radovick S, Boehm U, et al. Timing and completion of puberty in female mice depend on estrogen receptor alpha-signaling in kisspeptin neurons. Proc Natl Acad Sci USA. 2010 Dec;107(52):22693-8.

26 Madisen L, Zwingman TA, Sunkin SM, Oh $\mathrm{SW}$, Zariwala $\mathrm{HA}, \mathrm{Gu} \mathrm{H}$, et al. A robust and high-throughput Cre reporting and characterization system for the whole mouse brain. Nat Neurosci. 2010 Jan;13(1):133-40.

27 Bäckman CM, Malik N, Zhang Y, Shan L, Grinberg A, Hoffer BJ, et al. Characterization of a mouse strain expressing Cre recombinase from the $3^{\prime}$ untranslated region of the dopamine transporter locus. Genesis. 2006 Aug; 44(8):383-90.

28 Paxinos G, Halliday G, Watson C, Koutcherov Y, Wang H. Atlas of the Developing Mouse Brain at E17.5, P0, and. London: Academic Press; 2007. p. 6

29 Brancaccio M, Maywood ES, Chesham JE, Loudon AS, Hastings MH. A Gq-Ca2+ axis controls circuit-level encoding of circadian time in the suprachiasmatic nucleus. Neuron. 2013 May;78(4):714-28.

30 Armbruster BN, Li X, Pausch MH, Herlitze S, Roth BL. Evolving the lock to fit the key to create a family of $\mathrm{G}$ protein-coupled receptors potently activated by an inert ligand. Proc Natl Acad Sci USA. 2007 Mar;104(12):51638.

31 Kotani M, Detheux M, Vandenbogaerde A, Communi D, Vanderwinden JM, Le Poul E, et al. The metastasis suppressor gene KiSS-1 encodes kisspeptins, the natural ligands of the orphan G protein-coupled receptor GPR54. J Biol Chem. 2001 Sep;276(37):34631-6.
32 Franceschini I, Lomet D, Cateau M, Delsol G, Tillet Y, Caraty A. Kisspeptin immunoreactive cells of the ovine preoptic area and arcuate nucleus co-express estrogen receptor alpha. Neurosci Lett. 2006 Jul;401(3):22530.

33 Baleriola J, Jean Y, Troy C, Hengst U. Detection of Axonally Localized mRNAs in Brain Sections Using High-Resolution In Situ Hybridization. J Vis Exp. 2015 Jun;(100):e52799.

34 Veldhuis JD, Johnson ML. Cluster analysis: a simple, versatile, and robust algorithm for endocrine pulse detection. Am J Physiol. 1986 Apr;250(4 Pt 1):E486-93.

35 Song S, Li J, Zhu L, Cai L, Xu Q, Ling C, et al. Irregular $\mathrm{Ca}(2+)$ oscillations regulate transcription via cumulative spike duration and spike amplitude. J Biol Chem. 2012 Nov; 287(48):40246-55.

36 Nieto FR, Cobos EJ, Tejada MA, SánchezFernández C, González-Cano R, Cendán CM. Tetrodotoxin (TTX) as a therapeutic agent for pain. Mar Drugs. 2012 Feb;10(2):281-305.

37 Strupp M, Teufel J, Zwergal A, Schniepp R, Khodakhah K, Feil K. Aminopyridines for the treatment of neurologic disorders. Neurol Clin Pract. 2017 Feb;7(1):65-76.

38 Simms BA, Zamponi GW. Neuronal voltagegated calcium channels: structure, function, and dysfunction. Neuron. 2014 Apr;82(1): 24-45.

39 Constantin S, Jasoni C, Romanò N, Lee K, Herbison AE. Understanding calcium homeostasis in postnatal gonadotropin-releasing hormone neurons using cell-specific Pericam transgenics. Cell Calcium. 2012 MarApr;51(3-4):267-76.

40 Shin MC, Nonaka K, Wakita M, Yamaga T, Torii Y, Harakawa T, et al. Effects of tetanus toxin on spontaneous and evoked transmitter release at inhibitory and excitatory synapses in the rat SDCN neurons. Toxicon. 2012 Mar; 59(3):385-92.

41 Ferecskó AS, Jiruska P, Foss L, Powell AD, Chang WC, Sik A, et al. Structural and functional substrates of tetanus toxin in an animal model of temporal lobe epilepsy. Brain Struct Funct. 2015 Mar;220(2):1013-29.

42 Koo J, Choe HK, Kim HD, Chun SK, Son GH, Kim K. Effect of Mefloquine, a Gap Junction Blocker, on Circadian Period2 Gene Oscillation in the Mouse Suprachiasmatic Nucleus Ex Vivo. Endocrinol Metab (Seoul). 2015 Sep; 30(3):361-70.

43 Cruikshank SJ, Hopperstad M, Younger M, Connors BW, Spray DC, Srinivas M. Potent block of $\mathrm{Cx} 36$ and $\mathrm{Cx} 50$ gap junction channels by mefloquine. Proc Natl Acad Sci USA. 2004 Aug;101(33):12364-9.

44 Huang YS, Tseng YZ, Wu JC, Wang SM. Mechanism of oleic acid-induced gap junctional disassembly in rat cardiomyocytes. J Mol Cell Cardiol. 2004 Sep;37(3):755-66.

45 Stutzmann GE, Mattson MP. Endoplasmic reticulum $\mathrm{Ca}(2+)$ handling in excitable cells in health and disease. Pharmacol Rev. 2011 Sep;63(3):700-27. 
46 Irwin RP, Allen CN. Neuropeptide-mediated calcium signaling in the suprachiasmatic nucleus network. Eur J Neurosci. 2010 Nov; 32(9):1497-506.

47 Power JM, Sah P. Nuclear calcium signaling evoked by cholinergic stimulation in hippocampal CA1 pyramidal neurons. J Neurosci. 2002 May;22(9):3454-62.

48 Takahashi N, Omi A, Uchino H, Kudo Y. Different characteristics of cell volume and intracellular calcium ion concentration dynamics between the hippocampal CA1 and lateral cerebral cortex of male mouse brain slices during exposure to hypotonic stress. J Neurosci Res. 2018 Jan;96(1):117-27.

49 Roth BL. DREADDs for Neuroscientists. Neuron. 2016 Feb;89(4):683-94.

50 Stachniak TJ, Ghosh A, Sternson SM. Chemogenetic synaptic silencing of neural circuits localizes a hypothalamus $\rightarrow$ midbrain pathway for feeding behavior. Neuron. 2014 May; 82(4):797-808.

51 Higo S, Iijima N, Ozawa H. Characterisation of Kiss1r (Gpr54)-Expressing Neurones in the Arcuate Nucleus of the Female Rat Hypothalamus. J Neuroendocrinol. 2017 Feb;29(2): 29.

52 Gottsch ML, Popa SM, Lawhorn JK, Qiu J, Tonsfeldt KJ, Bosch MA, et al. Molecular properties of Kiss1 neurons in the arcuate nucleus of the mouse. Endocrinology. 2011 Nov; 152(11):4298-309.

53 DeFazio RA, Elias CF, Moenter SM. GABAergic transmission to kisspeptin neurons is differentially regulated by time of day and estradiol in female mice. J Neurosci. 2014 Dec; 34(49):16296-308.

54 Ikegami K, Minabe S, Ieda N, Goto T, Sugimoto A, Nakamura S, et al. Evidence of involvement of neurone-glia/neurone-neurone communications via gap junctions in synchronised activity of KNDy neurones. J Neuroendocrinol. 2017 Jun;29(6):29.

55 Whissell PD, Tohyama S, Martin LJ. The Use of DREADDs to Deconstruct Behavior. Front Genet. 2016 May; 7:70.

56 Campbell JN, Macosko EZ, Fenselau H, Pers $\mathrm{TH}$, Lyubetskaya A, Tenen D, et al. A molecular census of arcuate hypothalamus and median eminence cell types. Nat Neurosci. 2017 Mar;20(3):484-96.
57 Fu LY, van den Pol AN. Kisspeptin directly excites anorexigenic proopiomelanocortin neurons but inhibits orexigenic neuropeptide $\mathrm{Y}$ cells by an indirect synaptic mechanism. J Neurosci. 2010 Jul;30(30):10205-19.

58 Poling MC, Quennell JH, Anderson GM, Kauffman AS. Kisspeptin neurones do not directly signal to RFRP-3 neurones but RFRP-3 may directly modulate a subset of hypothalamic kisspeptin cells in mice. J Neuroendocrinol. 2013 Oct;25(10):876-86.

59 Navarro VM, Ruiz-Pino F, Sánchez-Garrido MA, García-Galiano D, Hobbs SJ, ManfrediLozano M, et al. Role of neurokinin B in the control of female puberty and its modulation by metabolic status. J Neurosci. 2012 Feb; 32(7):2388-97.

60 Gill JC, Navarro VM, Kwong C, Noel SD, Martin C, Xu S, et al. Increased neurokinin B (Tac2) expression in the mouse arcuate nucleus is an early marker of pubertal onset with differential sensitivity to sex steroid-negative feedback than Kiss1. Endocrinology. 2012 Oct;153(10):4883-93.

61 Wakabayashi Y, Nakada T, Murata K, Ohkura S, Mogi K, Navarro VM, et al. Neurokinin $\mathrm{B}$ and dynorphin $\mathrm{A}$ in kisspeptin neurons of the arcuate nucleus participate in generation of periodic oscillation of neural activity driving pulsatile gonadotropin-releasing hormone secretion in the goat. J Neurosci. 2010 Feb;30(8):3124-32.

62 Voliotis M, Li XF, De Burgh R, Lass G, Lightman SL, O'Byrne KT, et al. The Origin of GnRH Pulse Generation: An Integrative Mathematical-Experimental Approach. J Neurosci. 2019 Dec;39(49):9738-47.

63 Han SY, Kane G, Cheong I, Herbison AE. Characterization of GnRH pulse generator activity in male mice using GCaMP fiber photometry. Endocrinology. 2019 Mar;160(3): $557-67$.

64 Yip SH, Boehm U, Herbison AE, Campbell RE. Conditional viral tract tracing delineates the projections of the distinct kisspeptin neuron populations to gonadotropin-releasing hormone $(\mathrm{GnRH})$ neurons in the mouse. Endocrinology. 2015 Jul;156(7):2582-94.
65 Constantin S, Klenke U, Wray S. The calcium oscillator of GnRH-1 neurons is developmentally regulated. Endocrinology. 2010 Aug; 151(8):3863-73.

66 Glanowska KM, Burger LL, Moenter SM. Development of gonadotropin-releasing hormone secretion and pituitary response. J Neurosci. 2014 Nov;34(45):15060-9.

67 Nestor CC, Qiu J, Padilla SL, Zhang C, Bosch MA, Fan W, et al. Optogenetic stimulation of arcuate nucleus Kiss1 neurons reveals a steroid-dependent glutamatergic input to POMC and AgRP neurons in male mice. Mol Endocrinol. 2016 Jun;30(6):630-44.

68 Goodman RL, Hileman SM, Nestor CC, Porter KL, Connors JM, Hardy SL, et al. Kisspeptin, neurokinin $\mathrm{B}$, and dynorphin act in the arcuate nucleus to control activity of the $\mathrm{GnRH}$ pulse generator in ewes. Endocrinology. 2013 Nov; 154(11):4259-69.

69 Qiu J, Nestor CC, Zhang C, Padilla SL, Palmiter RD, Kelly MJ, et al. High-frequency stimulation-induced peptide release synchronizes arcuate kisspeptin neurons and excites GnRH neurons. eLife. 2016 Aug;5:e16246.

70 Ben-Ari Y, Gaiarsa JL, Tyzio R, Khazipov R. GABA: a pioneer transmitter that excites immature neurons and generates primitive oscillations. Physiol Rev. 2007 Oct;87(4):121584.

71 Marshall CJ, Desroziers E, McLennan T, Campbell RE. Defining subpopulations of arcuate nucleus GABA neurons in male, female, and prenatally androgenized female mice. Neuroendocrinology. 2017;105(2):157-69.

72 Sanz E, Quintana A, Deem JD, Steiner RA, Palmiter RD, McKnight GS. Fertility-regulating Kiss1 neurons arise from hypothalamic POMC-expressing progenitors. J Neurosci. 2015 Apr;35(14):5549-56.

73 Martínez de la Escalera G, Choi AL, Weiner RI. Generation and synchronization of gonadotropin-releasing hormone $(\mathrm{GnRH})$ pulses: intrinsic properties of the GT1-1 GnRH neuronal cell line. Proc Natl Acad Sci USA. 1992 Mar;89(5):1852-5.

74 Kim K, Ramirez VD. Dibutyryl cyclic adenosine monophosphate stimulates in vitro luteinizing hormone-releasing hormone release only from median eminence derived from ovariectomized, estradiol-primed rats. Brain Res. 1985 Sep;342(1):154-7. 